\title{
ACTED
}

Agence d'Aide à la Coopération Technique et au Développement Агентство по Техническому Сотрудничеству и Развитию Agency for Technical Cooperation and Development

\section{WAKHAN MISSION REPORT \\ Survey of the livelihood conditions and the governance framework among Wakhi and Kirghiz communities in Wakhan Woluswali, Afghanistan}

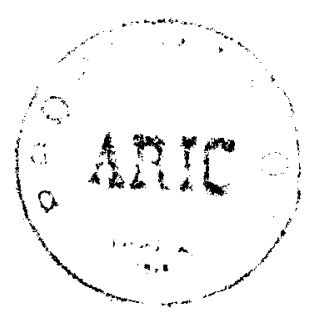

Sabine Felmy 


\section{Contents}

1 Introduction

2 Objectives of the mission

3 Statement of the historical background for the comprehension of the present situation

4 Findings of the mission

4.1 Power relations and social structure

Woluswali

Commander system

Wakhi community

Kirghiz community

4.2 Infrastructure development

Road infrastructure

Electricity

Drinking water

4.3 Agriculture

Crop-farming

Livestock-keeping

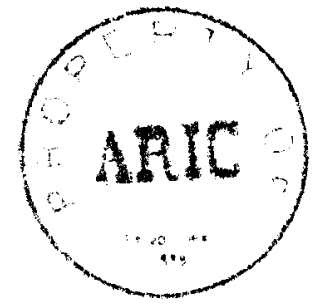

4.4 Education and health

Schools

Health facilities and surveys

4.5 Mobility, migration and non-agrarian income generation through wages and salaries

Migration

Non-agrarian income generation

Salariat

4.6 Exchange economy and entrepreneurship

4.7 Tourism and trophy-hunting

4.8 NGO activities at present

5 Conclusions and recommendations $\quad 24$

5.1 Wakhan Woluswali 27

5.2 Position of the Kirghiz 29

5.3 Potential for development and stakeholders 30

6 References 31

Appendix 1: Itinerary of the Wakhan mission from Taloqan to Murghab 33

Appendix 2: English translation of an article published in Frankfurter Rundschau No. 258 of 35

November 6,2000, p. 9: Hard times on the roof of the world

Appendix 3: List of Acronyms 


\section{Introduction}

Wakhan Woluswali is the administrative term for the northeastern narrow appendix-like strip of A fghan territory. Not only due to its topography and orography this area has a long record of being neglected within the context of Afghan administration, infrastructure development and spread of social amenities. The spiritual and political leader of the Wakhi community, Shah Ismael from Qala-e Panja, put it this way during our conversation: "To what country does Wakhan belong? We do not know if it is part of Afghanistan, Tajikistan or PR of China because we do not feel any interest and responsibility of a caring government and long-lasting effects of development measures here. Therefore my participation in the Loya Jirga and my recent journey to call on the ministeries in Kabul seem to have been in vain."

The territorial area of Wakhan Woluswali (Fig.1) covers $8936 \mathrm{~km}^{2}$ of mountainous country stretching between $2570 \mathrm{~m}$ and $7485 \mathrm{~m}$. Ecological zones vary from desert conditions in the valley bottoms to artemisia steppe in medium elevations and to meadows and grassy patches in the higher elevations forming what in local terminology is addressed as pamer (high pasture in Wakhi language). Thus inhabitable space is scarce and confined to mainly two ecological units:

- Agricultural settlements for irrigated crop farming are nearly exclusively located in the valley bottoms of the Amu Darya and the Ab-e Wakhan between $2550 \mathrm{~m}$ (Futur) and $3360 \mathrm{~m}$ (Sarhad-e Wakhan or locally more frequently called Sarhad-e Baroghil). Irrigated oases are situated on alluvial scree slopes, fans and river terraces within a steppe to semi-desert environment. Those comparatively flat and low-lying regions are the sole agro-ecologically suitable areas for irrigated crop farming of cereal and tuber crops such as wheat (Wakhi: ghedim; Triticum aestivum), barley (yirk; Hordeum vulgare), millet (jir, Panicum miliaceum), peas(shakh, Pisum sativum), beans (baqla, Vicia faba), potatoes (kachalu; Solanum tuberosum) and pulses (krosh; Lathyrus sativus). In small quantities rapeseed (sharsham), vetch and flax are cultivated in the lower-lying villages.

- The second ecological area of agricultural interest are the high pastures either located in the river valleys above the settlements in easy reach for proximity pastures or daily grazing grounds. The most valuable pastures are located in the Little Pamir - Pamir-e Khurd (Dari) or Kichik Pamir (Kirg.) - and the Great Pamir - Pamir-e Kalan (Dari) or Chong Pamir (Kirg.). Those extensive natural pastures are the wealth of the region which were praised as far back as during Marco Polo's travels (Polo 1984). The extended natural grazing grounds offer high quality fodder during the summer months and permit Wakhi mountain farmers seasonal usage and Kirghiz nomads to keep their herds there all-year-round (cf. Curzon 1896, Kreutzmann 1996, 2000, 2001, 2003). In the past the natural fodder resource has permitted a profitable animal husbandry which enabled the local Kirghiz to enjoy a substantial degree of wealth prior to the Saur Revolution (cf. Shahrani 1979). Events of the last quarter century have changed migration and utilization patterns and the success of agricultural enterprises dramatically. Herds are usually comprised of mainly sheep and goats (they are the prime marketable product of livestock-breeding), yaks in the higher elevations (mainly for home consumption and transport), horses, donkeys, and Bactrian camels (for riding and transport).

The Wakhan Woluswali is inhabited by two ethnic groups (see Fig. 1): Wakhi and Kirghiz. Both groups are on first sight distinguishable by their prime subsistence strategy. ${ }^{1}$ The Wakhi mountain

1) "Two major strategies are used to utilize the pasture potential of Western High Asia given the ecological constraints and socio-political circumstances. They are nomadic animal husbandry and combined mountain agriculture (Ehlers and Kreutzmann 2000):

(i) Nomadism incorporates the advantage of mobility. Traditionally nomadic groups were able to exploit natural resources at dispersed locations. Great distances, in the order of several hundred kilometres, separate economically valuable mountain pastures from winter camp sites, with areas of less economic interest lying between them. Functional migration cycles can be recognized in the region. They generally comprise long stays in high-altitude pastures during the summer with winter grazing in low-lying basins in the northern foothills or the plains of the Inner Asian mountain arc. The nomads depend on being tolerated as a mobile group and being able to pay grazing 


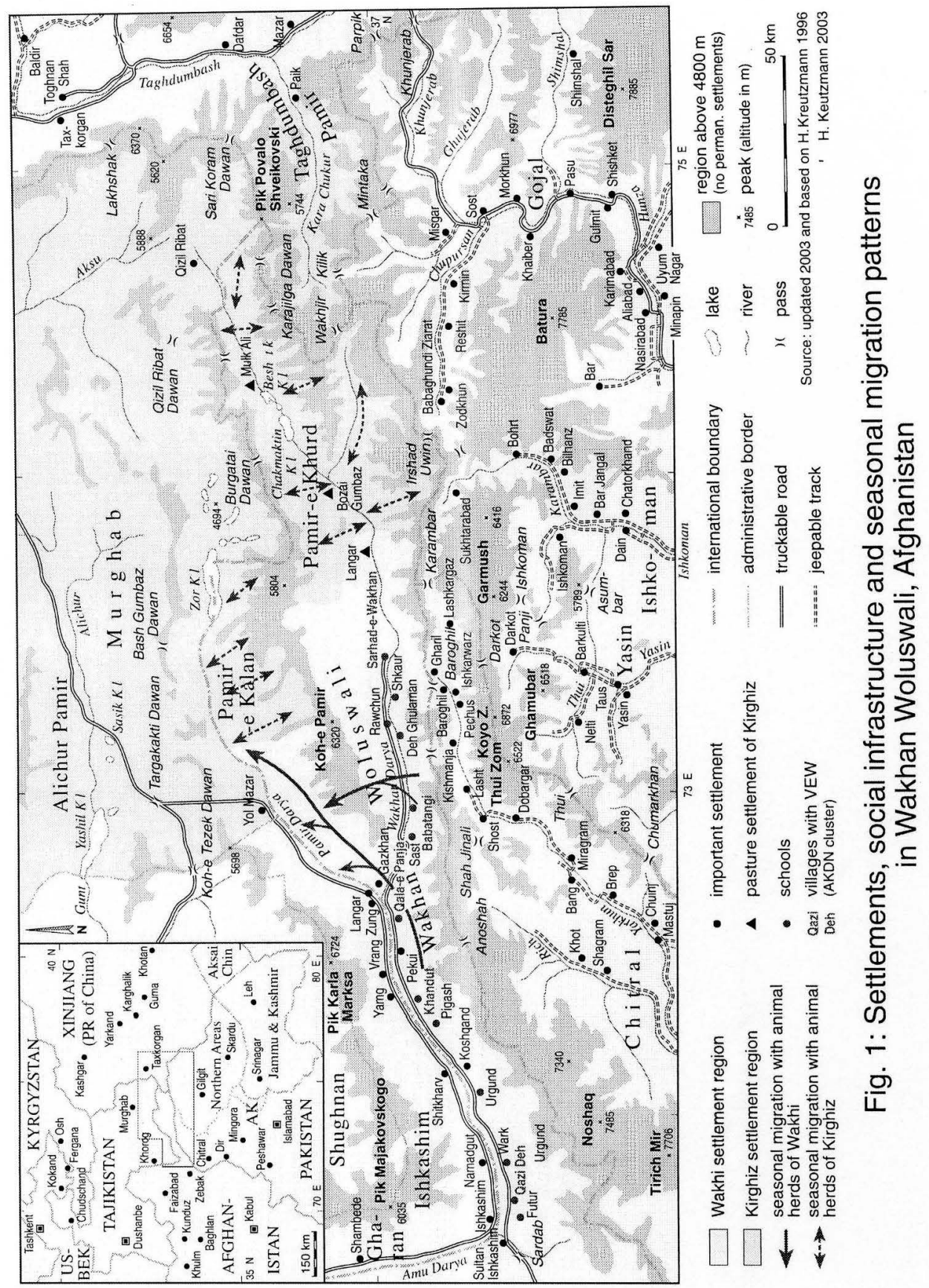

fees, if applicable, in both areas.

(ii) Combined mountain agriculture has the advantage of simultaneous fodder production in the permanent homesteads for herds which are grazed in the high pastures during the summers. The limiting factor here is the provision of up to nine months feed which has to be produced on private or common property village lands. The Wakhi houses are usually located at the upper levels of permanent settlements in single-crop farming areas. Consequently access to the pamir pastures involves shorter migrations and some mobility within the summer habitations. Fodder here is comparatively plentiful but only available for a short period, feed storage and transport to the homesteads are of limited importance.

Both approaches can result in competition for natural resources in the same location and they have frequently been discussed from that perspective" (quoted from Kreutzmann 2003). 
farmers follow a strategy which is based on combined mountain agriculture (cf. Ehlers \& Kreutzmann 2000). They speak a language called khikwar or sposik by themselves and Wakhi by others. Wakhi belongs to the Pamirian language group of the Eastern Iranian branch of the Iranian languages within the Indo-Iranian group. Kirghiz pastoralists follow in general a mountain nomadic approach to utilize the high pastures of the Afghan Pamirs. Their Kirghiz language belongs to the Altaic group and is closely related to neighbouring Turkic languages.

Besides language differences, Wakhi and Kirghiz follow different belief systems. Kirghiz communities traditionally comprise of Sunni Muslims, while the Wakhi almost exclusively belong to the Shia Ismaili sect which acknowledges the Aga Khan as their spiritual head. The religious practices influence daily life and local cultures as religious festivals and rituals play prominent roles beyond rites of passage. Kirghiz culture is characterized by the lifestyle of migrating pastoralists including transitory dwellings in the form of the round felt-covered yurts displaying artefacts of local folklore (cf. Dor and Naumann 1978, Kreutzmann 2001, 2003, Shahrani 1979). In contrast Wakhi houses are built of stone and mud-plastered walls and are scattered among the village lands in irrigated mountain oases. Wakhi herders migrate to high mountain pastures where simple houses provide shelter. The majority of household members remain in the villages where cultural life is centred at this time (cf. Felmy 1997, Kreutzmann 1996). Both life-styles exhibit close affinities to the different traditions and affiliations of the two groups.

The scattered population is given by the acting-Woluswal, Mullah M. Jon, in Khandut as consisting of 13400 inhabitants split-up in about 1100 Wakhi households in the villages located in the valley floor - nearly equally divided between the low-lying western Amu Darya or Pyandsh valley $(2570-2850 \mathrm{~m})$ and the higher-elevated settlements in the eastern Ab-e Wakhan valley $(2850-3360 \mathrm{~m})$. In addition there are $110 \mathrm{Kirghiz} k i b i t k a$ (yurt households or akoi (white yurts), in Wakhi kbirgo) in the Great Pamir and 140 Kirghiz households in the Little Pamir, all of them located above $3500 \mathrm{~m}$ asl.

About 80 years ago the population of A fghan Wakhan was given with 3500 inhabitants while it had doubled when an enquiry by the A fghan Ministry of Planning and Finnconsult was conducted by the mid-1970s (Kreutzmann 1996: 133). Their findings for Wakhan Woluswali were not very encouraging: "There is hardly any development potential in this area. The living conditions are hard, and development of the basic industries, agriculture and animal husbandry, would be more expensive than direct aid. However the economies of exploiting part of the peat resources available in the Pamirs ... are worth studying. Another probably more realistic way of improving the economy of the people of Wakhan would be to increase organized tourism in this area. A Marco Polo sheep hunting programme organized by the Afghan Tourism Organization has already been in effect for more than 10 years, and also mountain climbing tours have been organized. There is still, however, a good potential for increased tourism in Wakhan." (Finnconsult 1976: 26).

The theory of modernization as the only tool for development inspired that enquiry which stamped subsistence-oriented agriculture and animal husbandry as traditional and backward while tourism and trophy-hunting were labelled as modern. When the trophy-hunting camps were seasonally established the local farmers and husbanders enjoyed for the only time of the year medical services (cf. Petocz 1978). ${ }^{2}$ The highly sophisticated utilization of natural potential and the generated wealth enjoyed during the same time by very successful Kirghiz pastoralists escaped the scrutiny of the bureaucrats and consultants of the time. The then-leader of the Kirghiz community, Haji Rahman Qul (who died in exile in Turkey in 1990) enjoyed a livestock property of his own which was equal in size to the combined livestock herds of 1250 households

\footnotetext{
2) Such a luxury was subsequently only available during the presence of Soviet occupation forces which was highly appreciated by the Kirghiz leaders and which enabled them to access health facilities in neighbouring Murghab in case of complications. The present leader of the Kirghiz community, Abdur Rashid Khan, has been treated in Murghab hospital several times.
} 
of Wakhi and Kirghiz inhabiting Wakhan Woluswali today. His strong leadership and the introduction of the amanat system (long term herding arrangement by giving animals for safekeeping to herders; cf. Shahrani 1979: 179) have proved that the fame of the pasture potential of the Pamirs is a real property of the region and can be successfully utilized. Thus the potential of the Wakhan is presently not fully exploited and scope for improvement is ample.

\section{Objectives of the mission}

The overall objective of the Wakhan mission was to present an assessment of the present socioeconomic situation of the Wakhi mountain farmers and Kirghiz nomads in Wakhan Woluswali. The activities of other NGOs and government institutions needed an evaluation in order to identify the constraints and shortcomings as well as the potential for further interventions, supplementary packages and supporting measures of a needy population.

The mission tried to address the following questions:

- How is the present situation in Wakhan conceived and interpreted within the context of previous experiences and future potentials of infrastructure development?

- Who is in a position to identify and streamline the role of Wakhan within the Afghan nation state when it is based on historical considerations and economic potential?

- How are combined mountain agriculture and mountain nomadism in Wakhan interrelated?

- What role do they play for local subsistence strategies and market-oriented production?

- How is the overall nutritional situation structured among different social groups?

- What role Wakhan has played as an important supplier of live animals and livestock products for the regional market in Badakhshan and for the supra-regional markets of Kabul, Jalalabad, Taloqan, Qunduz and Mazar-e Sharif?

- How are the relationships between residents of Wakhan Woluswali and itinerant traders (saudegar), bazaar vendors and other businessmen?

- What impact is felt in Wakhan of migrant labour and non-agrarian income-generating strategies?

- Does education exist and play a role for professional careers and income generation from non-farm resources?

- How are the relations between genders structured and what role do they play in the division of labour in households and in agriculture?

- Are deficiencies from crop farming and livestock-keeping reflected in the nutritional patterns?

- What are the coping strategies of local vulnerable groups in times of need?

- How are supporting measures for the uplift of the local economy in Wakhan Woluswali structured and organized?

- Does a potential for ecotourism, trophy hunting, trekking and mountaineering exist under present and medium-term conditions?

The questions summarized here will be dealt with in the following by applying a systematic structure in which the findings of the mission are coordinated and presented. 


\section{Statement of the historical background for the comprehension of the present situation}

The administrative unit which is now addressed as Wakhan Woluswali was the result of international boundary creation during the "Great Game" (Kreutzmann 1996). The area of the Afghan administrative unit was created in the late $19^{\text {th }}$ century when the then superpowers Tsarist Russia and British India agreed upon creating Afghanistan as a buffer state. The philosophy of their consensus was that both superpowers should in no place of their spheres of influence have a common border. Thus neutralized or divided territories such as Persia, Transcaspia, Afghanistan, Xinjiang and Tibet had to play the role of buffer zones. In the area of our concern we are confronted with the narrowest strip of land separating the spheres of influences in any place. The shape of the Wakhan corridor or Wakhan strip is the vivid proof of colonial boundary-making with all its long-lasting effects and consequences.

To reach this goal former principalities such as Roshan, Shughnan, Gharan, Ishkashim and Wakhan had to be divided in two parts on either side of the Amu Darya. Their respective territories had spread across the Amu Darya river, but the colonial powers had followed the fashion of the time and that was to identify major rivers as natural boundaries (cf. maps in Kreutzmann 1996: 102). Therefore Wakhan was split into what is now Rajon Ishkashim in Tajikistan and Wakhan Woluswali within the Islamic State of Afghanistan. The same fate applies to the other former principalities who never featured that prominently in world politics as Wakhan did.

Both territories of Wakhan have experienced a most different development since. One could even state that during the "Cold War" this was not only one of the best-controlled frontiers in the world, but that at the same time the socio-economic development gap was nowhere wider than here. Within the Soviet Union education and health facilities were externally supported, highly subsidised and reached a very high standard which is nowhere enjoyed in the neighbouring countries not to mention in Afghanistan. The centralised Soviet economy supplied Rajon Ishkashim with all necessary food stuffs, fuel, coal and consumer goods at nominal cost based on a road infrastructure which was established nearly 70 years ago. The contrast to Wakhan Woluswali could not be bigger! Forgotten and neglected within the planning system of the Afghan ministerial set-up Wakhan Woluswali did not enjoy any facilities such as roads, hospitals, good schools, electricity, telephone lines etc. While mountain farmers in the Soviet system became professionals such as medical doctors, engineers and office workers their Afghan relatives and neighbours had to continue to make a meagre living basically from a subsistenceoriented agriculture (Kreutzmann 2000a, c).

All this has changed since the collapse of the Second World, i.e. the Soviet bloc, and the subsequent independence of Tajikistan and other Central Asian Republics. The living conditions on the right bank of the Amu Darya have substantially deteriorated and the inhabitants on the left bank of the river got on top of their neighbours by displaying their experiences how to run a subsistence-oriented agriculture as they have done for generations in times of severe hardships. While their neighbours have to go through a process of (re)- learning agricultural practices it is business as usual in Wakhan Woluswali with scope for major improvements.

Boundary-creation in this part of the world had detrimental effects on the exchange relations of the inhabitants of remote mountain valleys such as Wakhan. Nomadism of Kirghiz was hampered by new barriers and restrictions. M. Nazif Shahrani (1979) coined the term of "closed frontier nomadism" for the practice which has evolved since the hermetic closure of international boundaries. Up to the 1950s Kashgar was their prime trading destination, after the border closure Kabul took its place when once or twice during winter long-distance caravans took off from the Pamirs towards Afghanistan's capital bazaar. 
Wakhi mountain farmers have depended on non-agrarian sources of income like most mountain farmers. Their traditional niches included load-carrying, caravan transport, looting and smuggling, and the supply of food to traders, in addition there was a limited scope for trade by themselves. These extra sources dried immediately up when the "Cold War" began. The historical developments are highlighted here in order to emphasize that there are options for the future when border regimes change, communication lines are opened up, road infrastructure is upgraded and exchange relations can be improved. Then price differentials might be utilized between markets which have not enjoyed any communication for nearly three generations.

Thus the dead-end constellation of Wakhan as it appears on the maps could become advantageous in certain niches and incorporates potential for cross-border activities for the regional uplift and improvement of living conditions of the Wakhi and Kirghiz communities. Their interrelationship continues to exist on a mutual exchange basis: Wakhi provide wheat against Kirghiz livestock. The exchange value of 12 ser wheat per one fat-tailed sheep has not significantly changed since several decades (cf. Table 4c below).

After 1978 when the Kirghiz community fled into exile in Pakistan of which some families returned and had good relations with the Soviet occupation forces, inhabitants of Wakhan Woluswali mention brief phases of interest in infrastructure development by the Najibullah regime. After that salaries of teachers did not reach and bureaucratic interest faded. The regime of the commanders has replaced the previous state authorities. As there are not only the three commanders in charge of border security - there are as well in the major settlements subcommanders of sometimes little-known functions - the local populations realizes that they have more mouthes to feed with their contributions than it was experienced during the rule of Afghan administration prior to 1978 .

Present constellation: Most commanders of today originate from other areas in Badakhshan, mainly from Baharak, Warduj and Zardeu. Only one commander is of local origin: Fateh Ali Shah comes from Qala-e Panja and is presently in charge of the border security in Sarhad-e Wakhan. The commander in Qala-e Panja by the name of Khalil is supposed to come from Warduj, while the commander of Khandut by the name of Qadir Khan originates from Zardeu.

The regime of the commanders is a burden on the local community. After they had taken all the weapons (two machine-guns and twenty Kalashnikov automatic weapons) away from the local people they installed a regime of wheat contributions and livestock delivery which exert heavy dues and imposed taxation on the poor mountain farmers and nomads. In the perception of local residents they overrated their powers, extracted money resources and other valuables, exploited the scanty livelihoods of farmers and shepherds by taking away 200 livestock and about $3000 \mathrm{~kg}$ of wheat flour in 2001. In addition the barter trade in the field of opium against livestock and/or wheat flour is connected with them as well as with external businessmen from Badakhshan and other provinces. Last but not least the levy of toll tax extracted from businessmen and migrant workers has been a valuable source of income for the border commanders, but slows down mobility and exchange at the same time.

Presently this situation seems to change for the benefit of the local residents as the commanders are supposed to draw a provincial salary and are expected to refrain from previous forms of exploitation. To what extent this coincides with reality could not conclusively be established. The aim of local residents is to be confronted with a less exploiting form of local administration and a bureaucracy which concentrates its energies on the improvement of livelihoods and basic infrastructure. 


\section{Findings of the mission}

In the following we present the results of our enquiries in the Wakhan villages, interviews with concerned persons from different social layers and occupations. Our findings aim at giving a state-of-the art report about the present conditions in infrastructure development, the two sides of agriculture - crop farming and animal husbandry -, the status of education and health facilities, the degree of mobility/migration as a means to alleviate the pressure on local household resources, the appreciation and impact of an exchange economy with itinerant saudegar (businessmen) from outside and within the communities leading to the role of non-agarian income opportunities and entrepreneurism. The potential for tourism activities and trophyhunting are highlighted as well as the impact and the role of NGO activities to date. A special chapter is devoted to the particular situation of the Kirghiz as they are the most remote community in respect to access to infrastructure and social facilities.

\subsection{Power relations and social structure}

Prior to detailed assessment of development relevant aspects it needs to be stated how the social set-up is structured: At present the external influence in Wakhan Woluswali is imposed along two lines:

- Woluswali: civil administration as represented by the Afghan administrative and bureaucratic set-up, here visible through an acting-Woluswal in the person of Mullah M. Jon in Khandut who claims to be a bureaucrat and a civil judge as well. Very few people showed any esteem for him as a more powerful outside appointment (which is not uncommon) for the post is expected sometime in the future. As basically no noticeable impact by the presence of a Woluswali administration is felt it seems to be a long way back to the former influence which terminated more or less in the 1980s.

- Commander system: control institutions through the Badakhshan commander system. During the time of Najmuddin Khan (killed in November 1999) in charge of Eastern Badakhshan strict control and regional planning was exercised. The substantial growth of Ishkashim bazaar is due to his planning (as he outlined to us in an interview four years ago) and had a major impact on the local economy. Within Wakhan the regime of the commanders is felt as a regime of exploitation and heavy taxation without any beneficial impact. Livestock tax, flour tax and toll tax are the areas where dues are extracted. Since the Karzai government has taken its office and since Sador is in charge of Eastern Badakhshan the exploitative impact is less felt in Wakhan, but the situation is still not satisfactory. Only one commander, Fateh Ali Shah, is of local origin while all others are from Warduj, Baharak and Zardeu.

The inner structure of the two ethno-linguistic communities in Wakhan is quite different from the externally imposed groups but as well within as their practices and strategies for generating livelihoods and their social and denominational traditions vary:

- Wakhi community: within the Wakhi community power structures are related to affiliations of the former social structure. Since the former ruler of Wakhan, Mir Ali Mardan Shah, went into exile in Ishkoman (nowadays Pakistan) in 1883, the ruling family was strong and influential through his younger brothers, Sarbuland Ali Shah and Nasiruddin, who returned to their property in Qala-e Panja after exile (Kreutzmann 1996: 82). But after their death (around 1936) the former rulers' households (miri, shana) have lost their previous dominant position, but are to be classified among the bigger and better-off landowners with remote influence in politics.

Stronger influence is exercised by the saiyid (or syed) families who represent the Ismaili elite of the pir system. It stems from that time when the Aga Khan was far away and not regarded as the sole head of the community in daily life affairs. This position with a regional impact was held by the 
pir. Each household in Wakhan is affiliated with one pir or the other and belongs to the followership (murid) of one specific pir. In Wakhan two pir reside. Both families are former refugees from Soviet persecution in Central Asia during the 1920s and 1930s and fled from the right shore of the Amu Darya to the left shore in 1932 (cf. Kreutzmann 1996: 370) where they had already landholdings and a sizeable followership. The leader of the community is Shah Ismael, pir in Qala-e Panja (formerly from Shirgin, Rajon Ishkashim, GBAO). He succeeded his father, Saiyid M. Shah, in 1990 and is about 48 years of age. Approximately 450 households (out of 1100 Ismaili households) are his followers. Senior to him in age and being his uncle is the pir of Qazideh, Shah-e Langar (formerly of Zung, Rajon Ishkashim, GBAO) with a slightly smaller followership. The remainder of the Ismaili households is affiliated with the pir of Zebak (outside Wakhan on the road from Ishkashim towards Shah Silim pass and Chitral). In civil life pir and saiyid (their relatives) households are among the better-off and leading families (Fig. 2). Within the remainder of the society there are the village elders (arbab) and a group called klbaibere who enjoyed in the traditional society special rights (e.g. being exempted from load-carrying duties and certain taxes). These households are in general more affluent than the remainder of the society if and when they are not striken with a domestic opium problem. The ordinary people $(\underline{k}$ hik $)$ are more or less equal in political influence but still stratified in social terms. Of them about one fifth is in a medium position while four fifths are living in very poor conditions. They belong to the majority of pauperised people who during our visit were short of food grains and had to live on dried green plants (lakb) which they had predominantly collected in the mountain valleys and

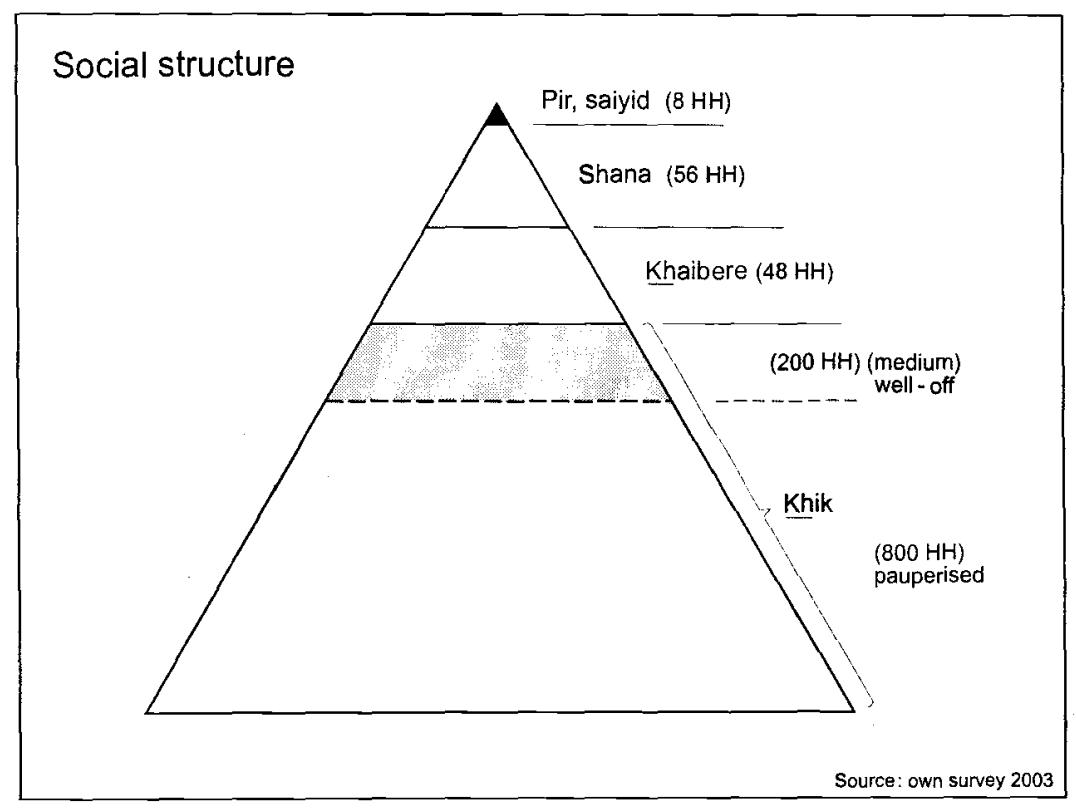

Fig. 2: Social structure of the Wakhi community in Wakhan Woluswali

which are cooked for consumption as soup.

When M. Nazif Shahrani studied the region in the mid-1970s he observed a social stratification of 25-30 affluent households (including miri, shana, saiyid, khaibere), 600 medium well-off households and 70 pauperised households $(=10 \%$, Shahrani 1979: 62-64, cf. Kreutzmann 1996: 146). In our estimate (Fig. 2) the so-called upper class is composed of roughly 110 households, while the remaining one thousand households are split-up in 200 medium and 800 pauperised households. The number and the societal share of the poor have significantly grown. The average household size ranges between 8-11 persons.

- Kirghiz community: The Kirghiz social set-up is quite different from the Ismaili structure. Although Shah Ismael as the representative of Wakhan in the Loya Jirga takes interest in the 
Kirghiz affairs and has discussions with Kirghiz leader Abdurrashid Khan from time to time the Sunni nomadic community is differently structured and had its own observer in Kabul.

During the rule and leadership of Haji Rahman Qul the Kirghiz ranged among the most affluent groups of northeastern Afghanistan. Rahman Qul was probably the richest person in this part and has proved that affluence and remoteness can co-exist. The downfall of the Kirghiz began with the exodus into Pakistan, four years of exile there and the resettlement of the majority in Turkey. The Kirghiz community we are discussing here is the followership of Abdurrashid Khan, about 50 families returned to the A fghan Pamirs between 1979 and 1982. In the Great Pamir about 110, in the Little Pamir about 140 households are residing. As there is no landholding and only animal herd size as the measurement of wealth it becomes quite obvious that the clan (seven households) of Abdurrashid Khan with more than 300 animals (62 yaks, 248 sheep and goats) is among the affluent ones, but that the clan (seven households) of Haji Osmon in Wakhjir with 640 animals is stronger as well as the clan ( 5 households) residing in Birgüt Uya with 450 animals. Other flock sizes in the Little Pamir could be very small such as 21 animals for three households (data according to Focus survey, Aug-Sep 1999). Political influence is strongest with Abdurrashid Khan who is said to be quite amicably linked to the security personnel on the northern side of the boundary. In local esteem the Kirghiz in Little Pamir fare better than the Kirghiz of the Great Pamir. The latter are suffering from the remotest location and very limited exchange opportunities (only with Tajikistan) while the Little Pamir is controlling a central position towards Pakistan, China and Tajikistan. The regime of the commanders is detrimentally felt here as well especially in respect to livestock taxes and toll tax.

This short introduction might support a better understanding of the following aspects relevant for the implementation of relevant development packages.

\subsection{Infrastructure development}

A lack of basic amenities is visible everywhere in Wakhan Woluswali and the region could be described as a remote, somehow "forgotten" (as Shah Ismael puts it) valley and a cut-off location in many ways when it comes to the participation in infrastructure development in the past and the present.

\section{- Road infrastructure}

The infrastructure life-line of Wakhan is the $192 \mathrm{~km}$-long truckable dirt road from Ishkashim through the valley bottom all the way to Sarhad-e Wakhan. There the road terminates and has no connection to any of the Kirghiz communities. The road was constructed in different sections during the Daud regime which is still appreciated by the local inhabitants as the most dedicated to infrastructure development in Wakhan. Four bridges were erected in the 1970 s, two with the help of GTZ close to Qala-e Panja.

The present situation is like this. After Focus decided last year to terminate the distribution of humanitarian aid to Wakhi households (which they had started in 1997) they shifted to a foodfor-work programme in road construction in 2003. Focus has offered two months of road work this year in which nearly all village communities and all households (i.e. Wakhi people) participated. In the initial part of the road commencing from Ishkashim up to Qazideh via Futur bridges and culverts have been constructed (in a cooperative effort with Afghan Aid). All the rest of the remaining $175 \mathrm{~km}$ stretch through the valley needs much more work in bridges and culverts. The food-for-work programme covered basically the easy to be repaired sections of the road while all sections which would be affording engineerial participation and higher technical and material input were excluded. This creates problems for travelling. As numerous irrigation channels cross the road alignment culverts would be the only sensible solution in the long run to avoid constant destruction of water courses. 
Major obstacles especially during July-August when glacier melt is at its peak are faced by rivers and rivulets which have to be crossed as bridges are missing or only feasible for donkey transport. A third category of problems is created by swampy sections of the road where groundwater is close and peat bogs and swamps are to be crossed.

There would be scope for much more roadwork, but as the teamleader of the Focus food-forwork distribution programme, Azmudin, who originates from Faizabad, put it: "The local food deficit has been measured as up to eight months deficiency (survey by Focus and Unicef), but donor funds could be attracted only for two months of road construction. We will finish the work soon as the season is short, and the road will not be in a good condition."

Despite the unsatisfactory manner in which the road work was accomplished, the impact of the improvemnent of the road is not negligible. The observation that only three vehicles are owned by residents from Wakhan Woluswali disguises the fact that the road improvement has increased exchange between Ishkashim bazaar and Wakhan. One Toyota hilux pick-up is owned by Shah Ismael (although the vehicle is not in working condition at the moment), two Russian Ural trucks were purchased by two of the three successful businessmen from Wakhan during the last year: Ramazonbhoy from Pigash purchased his truck a year ago, Muminbhoy from Tapc (near Babatangi in the upper valley) purchased his truck two months ago. Both transport mainly the goods of itinerant saudegar (businessmen) up the valley who barter goods with local residents against livestock.

Focus is the only institution offering food-for-work programmes in Wakhan, other projects include the construction of two clinics in Ishkashim and Khandut and three schools in Futur, Qazideh and Khandut.

Although most people have no direct benefit from road construction many interview partners mentioned the road with high priority. This relates to the expectation that extremely high prices are presently fetched by businessmen due to the lack of good accessibility and that basic consumer goods would be available at reasonable prices and sufficient quantities once the road is improved.

Azmudin of Focus mentioned that there are tentative plans of extending the road to the A fghan Pamirs. This is a priority put forward by the Kirghiz community who sees in the long run more trading potential within Afghanistan and via an Afghan road network than with cross-border traders where the uncontrollable international and bilateral political climate is involved. This regime governs whether borders are open or closed. At present the passes leading into Pakistan are closed due to bilateral political collisions.

The access to the Great Pamir would be via Gazkhan (see Fig. 1) and would cover a distance of $100 \mathrm{~km}$. The connection to the Little Pamir is envisaged from Sarhad-e Wakhan via Langar and Bozai Gumbaz closing a distance of $90 \mathrm{~km}$. Both alignments would traverse very difficult terrain and then connect with truckable tracks which are to be found in the Little Pamir from the times of Soviet occupation and which would connect all the way to the Tajik border at Kizil Robat via Ghundjibhoi. The Great Pamir access would connect to the link at the Tajik border west of Zor Köl lake.

\section{- Electricity}

Besides road construction the provision of electricity is of high priority in all settlements. At present no electricity is provided anywhere besides the two or three generators in affluent households. Hydro-electricity could be tapped in many decentralized places, as well as wind or solar energy as a convertible source. Three engineers of Focus have been surveying the central valley between Khandut and Gazkhan for identifying proper sites for small hydro-electricity schemes. 


\section{- Drinking water}

In most settlements spring water (kiike yüpk) is available although it is not clear if in sufficient quantities all year-long. At present the distances of water collection increase during the cold seasons when small streams from glacier water (yaze yüpk) dry up. Freezing of pipelines would be an obstacle for projects aiming at providing safe drinking water to the villagers throughout the year. Probably it would be necessary to dig ditches for sinking the pipes into the ground. This could well be a food-for-work programme in certain villages.

Particular villages such as Urgund are hardest-hit with very poor drinking water quality due to the prevalence of high quantities of suspended matter (affecting not only the drinking water but as well the irrigation of crops) in the glacier-melt water. Poor livelihoods there could be significantly improved through a water scheme which either supplies spring water from a distance and/or would engage in the construction of sedimentation tanks of higher efficiency and stability than the existing ones.

\section{- Other infrastructure}

It should be mentioned that there is no post office and no civil telephone line available to the public of Wakhan Woluswali. There seems to be a telephone line managed by the commanders in charge, but reports about its usefulness are quite controversial as is the state of poles and lines which are visible along the road

\subsection{Agriculture}

The agro-ecology of Wakhan Woluswali can be divided in four zones:

- The lower part of the valley (2550-2700m) enjoys most favourable conditions for cultivation. Here crop farming is the dominant factor of combined mountain agriculture and livestockkeeping is of secondary importance. A few animals are kept, but nobody approaches remote summer pastures, all animals are put on proximity pastures on a daily basis. The cultivars are composed of wheat, barley, beans and peas. Small parcels contain millet (Panicum miliaceum), alfalfa (Medicago sativa), clover and other leguminous plants. A growing importance can be attributed to kitchen gardens with a selection of vegetables.

- The central part of the valley $(2700-2900 \mathrm{~m})$ is characterized by a fading importance of beans in the selection of cultivars. Livestock gains in importance and for some better-off households herds can get to sizes which make it feasible to send them to remote summer grazing grounds in the Great Pamir where Wakhi villages have traditional grazing rights (cf. Fig. 1).

- The upper part (mainly villages located in the Ab-e Wakhan valley, 2900-3600m) features only wheat, barley, peas and Latbyrus sativus (krosh) as bread crops, no bean cultivation anymore. Animal husbandry becomes more important and herd sizes in general, but especially of the better-off people increase substantially.

- The Great and Little Pamir (above $3500 \mathrm{~m}$ ) are devoid of any cultivation, only in Langar some fields have been developed. Generally these are the grazing grounds of the Kirghiz nomads, although the western part of the Pamir-e Kalan is reserved for summer grazing by Wakhi shepherds (cf. Fig. 1). There are no disputes about pastures in this part. In contrast here is still ample scope for bigger herds as was usual during the 1970s.

Besides this stratification based on orography, agricultural practices and traditions there is in all zones a wide variation in land-holdings and herd sizes. The most affluent household of Qalae Panja easily outnumbers the poorest farmer by a factor of 30 when it comes to landholding and herds. There are quite a number of households without any livestock or the occasional cow for daily milk consumption. 
The same applies for animal herds among Kirghiz. In the Great Pamir (Chong Pamir) the ownership of sheep varies 28 and 120, while in the Little Pamir household ownership could be as low as 1-2 sheep, and as high as 70-75 per yurt. The assessment of crop-farming and livestockbreeding has to keep this variability in mind. As stated above the number of households at the lower end of the social scale is high and increasing, the mass of the population is trying to survive at the margin. Any crisis or unexpected event can lead to disastrous livelihood conditions.

\section{- Crop-farming}

Where crop-farming is the dominant activity coping strategies in times of need are centred around the collection of green plant (lakh), a wild spinach-like plant which is collected in the mountain valleys, dried and eaten in a watery soup. The gathering of this naturally available plant is a strong indicator for deficient grain-production and the failure of other sources of income. The length of the "green plant" eating period - which causes quite severe weakness and fatigue as neither protein, oil and salt are available shows how big the production deficit is. We were told that these periods could be as long as four months for certain households.

An important crop for the poor is Latbyrus sativus (krosh) which when consumed in too high quantities causes lathyrism, in Wakhan popularly called "polio" as it appears to reduce the control of leg and arm movements and the sense of equilibrium is fading. The krosh crop is appreciated by the poor not only because of good yield even on poor soil, but as well as it is the early ripening crop in summer-autumn and its harvest concludes the summer starvation period.

Seed selection and/or rotation is not part of tradition. With improved wheat varieties and faster growing barley varieties yield could be increased and harvests could be available earlier. Presently the farmers basically produce their own seed and are always challenged by the option to keep seed or to eat it. This conflict has been addressed through Focus and now AKDN through the distribution of wheat packages and through the operation of wheat and grain stores in the villages where on an interest-free basis wheat (and mineral fertilizer) loans can be aquired within certain margins. The loan has to be returned after harvest. The same system of wheat loans is part of the tradition - not only in Wakhan, but in neighbouring valleys as well. The religious taxes (zakat) are collected in kind and stored in the villages. In times of shortage the religious leaders give wheat to the needy as a gift or on loan basis. This storage system could be identified as a local coping strategy to share and reduce risk and to avoid social unrest in the local communities.

When NGOs have offered mineral fertilizer farmers readily accepted the offer and confirmed that yields increased significantly. No farmer ever purchased fertilizer on his own account in a bazaar.

In Wakhan landholdings in general are too small (with the exception of the leading families who even can afford to practice fallow). During our interviews we were surprised how little efforts had been undertaken in the recent past in respect of bringing new land under cultivation. The construction of irrigation channels, the improvement of sedimentation tanks to filter the suspended matter from "glacier milk" (without any nutritional and soil-improvement value) and the development of new village lands are prime targets for the improvement of the physical agricultural infrastructure.

\section{- Livestock-ke eping}

The aspect of herd sizes and the varying appreciation and importance of livestock for the agricultural practices have been mentioned above. Here the same applies like in other communities:

- Bovines are mainly kept for domestic purposes. Wakhi farmers need a cow for milk production to satisfy the milk demand for their basic diet of salted milk tea and bread. The households who can afford more cattle are the better-off. In Kirghiz yurt households bovines are of the same 
importance for domestic consumption. The Kirghiz keep yak and no cows (cf. Kreutzmann 2003) and make ample use of all products furnished by them.

- Ovines are held for the markets. The valuable exchange commodity of fat-tailed sheep appears to be the prime currency. While Wakhi farmers exchange the occasional sheep and the more affluent up to five, the Kirghiz have to market more animals as they have to satisfy through their animals their wheat flour needs in total.

Livestock-keeping and animal breeding are risky undertakings. You can gain a lot and you can loose a lot. The latter happened to the breeders in spring of 2003 when late snowfalls caused heavy losses in livestock. In addition in some villages such as Qala-e Panja animal diseases (including foot-and-mouth-disease) reduced the herd sizes to nearly half. The villages with a reputation of prevalent animal diseases are not accepted with their herds in summer pastures and grazing grounds which they share with others. No veterinary service has been made available to them. For the first time AKDN sent this year a young man from Wakhan for veterinary training to Kabul. He did not return yet.

In some villages the provision of winter fodder is a scarcity factor for livestock-keeping. The prolonged cold season affords substantial stocks of green fodder and straw. Some villages do not bring back their livestock in winter, they keep it either in the Great Pamir pastures such as Djilmasirt where normally less snowfall occurs than in the permanent settlements or they give their livestock to the custody of Kirghiz nomads for the cold season which costs a fee. Only a few households with significant herds follow these practices. There are quite a number of Wakhi households with no livestock at all.

Any scheme to be implemented in the livestock sector needs to look on the improvement of animal health, fodder production for the cold season (in quantitative and qualitative terms) in order to enable those household to keep livestock which are at present devoid of any.

It should be mentioned that these animal husbanders and shepherds are basically vegetarians in their diet. Many households have as rarely as once a year or not at all meat dishes on the menu. The regular meal consists of saltish milk- tea with bread three times a day when stocks are plentiful. It can be reduced to twice a day tea and bread. When stocks are low only "green plant" soup is offered.

\subsection{Education and health}

The assessment of the educational status and the extent of accessible health facilities is characterized by the observation that even where there are facilities the quality is extremely poor. Although the first primary school of Wakhan was established in Qala-e Panja nearly half a century ago the quality and effect of education is appalling.

\section{- Schools}

There are 13 schools (Tab. 1) which basically do not deserve that physical description. The buildings are empty mural structures without doors and glass windows. Furniture is not existing, rarely a black board is available and/or a log for sitting. The assessment of this deficit was overcome by Unicef in providing tents as classroom replacements to several villages where a single tent costs US $\$ 600$. In most cases at least three or four of these tents were provided. For the sum spent on tents longer-lasting buildings could have been constructed by the village communities who rate education as high on their priority list and who sent their children on daily sojourns to school which last up to three hours per way. In winter schools are closed for three months.

The attendance was fairly good during our unexpected visit. The high attendance might be contributed to the fact that during the last two months daily a ration of tetra milk packs was 
issued to the students and teachers (sponsored by Aga Khan Foundation and the US Department of Agriculture).

\section{Table 1: Schools in Wakhan}

\begin{tabular}{|l|l|l|}
\hline Primary school & Secondary school & High school \\
\hline Wark & Futur & Qazideh \\
\hline Urgund (recently upgraded) & Pigash & Khandut \\
\hline Sast & Qala-e Panja & \\
\hline Shkaur & Babatangi & \\
\hline Deh Ghulaman & Sarhad-e Wakhan & \\
\hline Rawchun & & \\
\hline
\end{tabular}

Source: own survey

The attributed high priority to education is difficult to be comprehended. Generally girls are sent to school for basic instruction up to class 6 (Tab. 2). In higher classes the participation of girls fades. Nobody could name us a girl which had finished high school in Wakhan yet. The only persons who go through the whole system are boys. If they manage to go through the whole system they are predestined for becoming local teachers in their villages. All teachers in Qala-e Panja secondary school qualified either from Khandut or Ishkashim high school. None of them had received further education not to mention teacher's training. Last year was the first year since many that teachers received a salary of 1500 Afghani per month. Since December 2002 no salaries have been paid to teachers and other government employees. The teachers claim that they still survive on savings from last year's payments and their afternoon engagement in agriculture. In all of Wakhan we heard of two female teachers, one seems to be an experienced persons who is teaching for a long time. The second female teacher originates from Pakistan and married a Wakhi migrant worker before settling with her spouse in Wakhan. She got eight years of schooling in the Chupursan valley in Hunza, sufficient to become a teacher here. The emphasis parents put on education might relate to the observations of migrant workers in Pakistan where the standard of education (at least in the Ismaili communities) is much higher and has enabled the people to generate a comparatively better living standard. a recent survey in the central and upper settlements of Wakhan (on basis of one in three households) revealed: Adult literacy is $14 \%$ for men, $3 \%$ for women. $60 \%$ of the $7-14$ year-old boys and $22 \%$ of the $7-14$ yearold girls surveyed were in school (Duncan \& Duncan 2002: 3).

Again we could not find a single student who continued education after leaving high school and who built a professional career through further studies. The observation reflects the poor quality of teaching. No school books are available, in Qala-e Panja. The headmaster Aminuddin stated that out of the 67 households (app. 600 persons) in Qala-e Panja only 5 to 6 families can afford to purchase school books. Some classes ${ }^{3}$ are taught with only one book in the hand of the teacher. Besides providing school tents Unicef engaged in the distribution of teaching materials as well. AKDN started last month a survey on the quality of teaching. To improve the quality of teaching it is required that buildings receive a facelift, teachers are trained, not only within the subjects which is more than necessary, but as well in methods of teaching.

Although the teachers are mainly from the own community complaints about their social behaviour could not be overheard. There seem to be a number of teachers involved in opium (teryak) consumption, if not in distribution. This accusation was stated in written complaint with the newly appointed governor of Badakhshan in Faizabad.

\footnotetext{
$\left.{ }^{3}\right)$ Subjects taught include: Dari, Pashto, Arabic, English, Mathematics, Chemistry, Physics, Biology, Geography, Ethics, Holy Quran, Hadith, History, and Physical Education
} 
Table 2: Class attendance and gender distribution in Qala-e Panja secondary school

\begin{tabular}{|c|c|c|c|}
\hline Class & Boys & Girls & $\begin{array}{l}\text { Percentage } \\
\text { of girls }\end{array}$ \\
\hline 1 & 18 & 11 & 37.9 \\
\hline 2 & 13 & 14 & 51.8 \\
\hline 3 & 17 & 11 & 39.3 \\
\hline 4 & 15 & 6 & 28.6 \\
\hline 5 & 10 & 5 & 33.3 \\
\hline 6 & 8 & 3 & 27.2 \\
\hline 7 & 11 & 4 & 26.6 \\
\hline 8 & 12 & 1 & 7.7 \\
\hline 9 & 12 & 0 & 0 \\
\hline
\end{tabular}

Source: data provided by headmaster Aminuddin

\section{- Health facilities and surveys}

Health infrastructure is lacking to a great extent. There is no permanent health clinic or a coordinated community health programme. Presently two clinics are under construction in Ishkashim and in Khandut. AKDN plans to establish them as focal points for the provision of access to health facilities. At present none is operating. In Ishkashim there is a clinic jointly operated by MSF and the Ministry of Public Health. Here general practice is available and ten beds are available for in-patients, not reserved for patients from Wakhan, but as well for ailing people from Ishkashim, Zebak and Gharan. In August-September 2003 MSF is opening a TB clinic in Ishkashim. It is expected that $120 \mathrm{~TB}$ cases are to be registered in Badakhshan. In order to avoid spreading of TB a thorough therapy under strict control is aimed at. In June 1999, a medical doctor and a nurse from MSF visited Wakhan and reported about a $46 \%$ malnutrition among children. In August 2002, MSF started to train 4 workers to run 'health posts' in four locations between Qala-e Panja and Qazi Deh in a measure to provide the very basics in locations which can be accessed under two-days journey.

ORA was operating two opium-addicts rehabilitation centres ${ }^{+}$from 1998-2001 in Qazideh and Khandut with mixed success which finally led to the closure and lack of previously provided EU funds. Nevertheless, ORA is back in Wakhan with a project in health training. The programme is based on a survey (Duncan \& Duncan 2002) which highlighted the poor state of health and lack of facilities. The crude mortality rate of 41 per 1000 population per year $(67 \%$ of these deaths are children under 5 years old) is higher than Afghanistan's average which in itself is among the highest in Asia.. The difficult situation for children is reflected in the figure of 314 per 100000 for the mortality rate under 5 years. Poor state of hygiene, lacking access to medical check-ups and professional treatment are the general features to be addressed here:

\footnotetext{
${ }^{4}$ ) These so-called Najat clinics were not only operated in Wakhan, but as well in other border districts such as Shughnan, Zebak and Ishkasim with a high drug addiction problem. Opium (teryak) was traditionally the only medical drug available and functioned as an appetite suppressant at the same time. Therefore in times of tension and supply shortages the opium consume has increased as well in the Wakhi as in the Kirghiz areas. In the mid19070s Shahrani (1979: 138) estimated that about one hundred persons were consuming opium regularly. This number is now significantly higher.
} 
- Main causes of death in children under 5 are unexplained neonatal death, respiratory illness, measles and abdominal causes.

- $25 \%$ of 2 year olds and $50 \%$ of 1 year olds are malnourished. - Vaccination coverage is around $75 \%$ for measles and polio, but only $35 \%$ for DTP and
BCG.

- $\quad 49 \%$ of women of child-bearing age have had no tetanus toxoid vaccination and only 18\% have had 3 doses. (Duncan \& Duncan 2002: 3)

The ORA approach seems to be a sensible approach to mitigate the severe shortcomings in child care by training local women in the field of traditional birth attendance, hygiene and child feeding. It will be a long way to go for Wakhan to have any kind of access to medical facilities, especially in cases of emergency.

\subsection{Mobility, migration and non-agratian income generation through wages and salaries}

\section{- Migration}

Outmigration is a well-known coping strategy not only in mountain regions but very common and part of the tradition in the Hindukush, Karakoram and Pamirs. In the Wakhan context our interview partners confirmed that outmigration in times of little or less agticultural work was quite common especially during winter and spring. There are two target regions of particular interest for migrants:

- During the period of internal insecurity within A fghanistan when it was not safe to travel on domestic roads a number of males sought an outlet by taken-up employment in Pakistan, in particular in the Ismaili settlements of Chitral, Gilgit and Hunza.. In contrast to seasonal migration into neighbouring Chitral the journey to Gilgit and Hunza afforded an investment which would only be feasible for longer periods. We talked to some people who had spent between one to three years there. The climax of this migration seems to be over due to a number of reasons. First of all, wages are not particularly high in Pakistan and it is a measure of dire needs to go there for prolonged stints of work. The Pakistan authorities have made it more difficult for Afghan citizens to stay in Pakistani villages since $9 / 11$ when they started to search villages for them in order to send them back. Third, at present the political relations between Afghanistan and Pakistan are strained with the effect that the two major passes connecting the region with Chitral - Shah Silim connecting Zebak with the Lutkoh valley, and Baroghil between Sarhad-e Wakhan and the Yarkhun Valley - are closed for migrants and exchange. Although crossing is presently not impossible the cost of travelling increases under those circumstances and the poor are the first who cannot afford such an investment. Nevertheless, our interview partners reported about a number of males in Pakistan at present of whom they have no news. These migrants are just relieving the household from an additional eater, but are normally not in a position to save anything from their wages and/or to send remittances of any kind to support their families in Wakhan.

- Since the last two years major changes have occurred. More people have left Wakhan for other areas in Badakhshan such as Baharak and Faizabad, and even for Tarkhar and Qunduz to seek low-paid employment in Afghanistan as load-carriers, labourers in road construction and as helpers in bazaars. The same applies here that basically no savings can be accumulated from those wages and that not much communication takes place between migrants and their family members. 
Outmigration in general could be reduced further by more work opportunities locally. The presently executed food-for-work programme along the Wakhan road has proved the severe need for non-agarian income to cope with the production deficits from agriculture.

\section{- Non-agrarian income generation}

Within the valley there does not exist a cash economy hiring wage labourers. Most of the business is executed in a barter system. The village specialists such as masons, carpenters, blacksmiths, weavers, supervisors of irrigation channels (mirab) and owners of water-mills (khedorg) are remunerated once a year by the concerned households for which they offer their services through a small quantity of grain, or in the case of several days of continuous work through food provided during their working period plus a certain quantity of wheat for the work (Tab. 3).

Tab. 3: Village specialists and their remuneration

\begin{tabular}{|l|l|}
\hline Profession & Remuneration \\
\hline Irrigation channel supervisor & $\begin{array}{l}\text { Once a year } 1 \text { ser of wheat from the } \\
\text { participating households }\end{array}$ \\
\hline Water-mill owner & $\begin{array}{l}\text { From every sack of wheat he receives one } \\
\text { small shovel of wheat flour }\end{array}$ \\
\hline Blacksmith & $\begin{array}{l}\text { Who is in need of the service of the blacksmith } \\
\text { will provide the material (scrap iron etc.) for } \\
\text { the required tool, other households provide } \\
\text { the charcoal; all households provide the } \\
\text { blacksmith for his services with } 1 \text { ser of wheat } \\
\text { after harvest }\end{array}$ \\
\hline Mason and carpenter & $\begin{array}{l}\text { All material provided by the customer; food } \\
\text { served by him during the days of labour, plus a } \\
\text { small remuneration for the work }\end{array}$ \\
\hline Weaver of coarse carpets $($ palos) & $\begin{array}{l}\text { Material provided by the customer, as well as } \\
\text { food for about four to five days of work, plus } \\
\text { a remuneration of } 1 \text { ser of wheat per day }\end{array}$ \\
\hline Khalifa (Ismaili clergyman) & $\begin{array}{l}\text { According to services provided during rites of } \\
\text { passage different remunerations apply }\end{array}$ \\
\hline
\end{tabular}

Source: own survey in July 2003

\section{- Salariat}

The group which is eligible to draw a salary was called by sociologist Hamza Alavi the "salariat" and could be one of the very influential in local politics and being a role model for commitment to education. To this group belong in Wakhan the government officials including the Woluswal and his assistant. The biggest group is comprised of teachers and probably conscribed soldiers and militiamen.

All have in common that no salary was paid to them in 2003 up to date. Some of our interview partners claimed that they still have some savings from last year's payment which was one of the first in so many years and which established some trust in the Karzai Government.

Without a monetary income they fail to stimulate the local non-agarian economy. 


\subsection{Exchange economy and entrepreneurship}

Despite basically no cash economy in Wakhan money as a unit of calculation and fixing barter values plays a major role and the new Karzai money is the unit of calculation in Afghani. Prices differ quite substantially from location to location. Transport of goods from the bazaars in Kabul, Jalalabad, Qunduz and Taloqan permit their investors some substantial gain. Improved road conditions from the major urban centres to Faizabad and Baharak and onwards to Ishkashim have lowered transport costs and increased the frequency of vehicle arrivals in Ishkashim. While four years ago the bazaar of Ishkashim was very small with less than 50 shops of which only a few were open, the bazaar infrastructure has changed and the bazaar has grown to more than 300 shops which mainly have been constructed during the last two years and attracted local vendors and a few affluent and potent businessmen from Baharak and Faizabad. The latter are the two major supply centres for Ishkashim and consequently for Wakhan.

It is difficult to establish how many vehicles are arriving in Ishkashim on a daily basis as seasonality is of importance. During our stay about five vehicles - mini busses, pick-ups and/or trucks - arrived in Ishkashim per day. According to the Ishkashim Woluswal, Syed Imran Khan, the transport of goods was previously about 40-45 Afghani/ser and has come down to 10 Afghani/ser for goods from Baharak and $15 \mathrm{Afghani} /$ ser from Faizabad nowadays. A further 30 A fghani/ ser could be required to bring goods to the end of the Wakhan road to Sarhad-e Wakhan (about 20 to Qala-e Panja).

A big rush of vehicles occurs when the businessman (saudegar) arrive in spring to give goods on loan to the villagers in Wakhan Woluswali. They pay back their dues in autumn through wheat and livestock at higher costs (Table 4a). In between are the prices for purchases in Ishkashim bazaar on credit.

Table 4a: Comparison of prices (in Afghani) for basic goods between Ishkashim Bazaar vendors and itinerant traders in Wakhan

\begin{tabular}{|l|r|r|l|}
\hline Commodity & $\begin{array}{l}\text { Ishkashim } \\
\text { Bazaar } \\
\text { (cash purchase) }\end{array}$ & $\begin{array}{l}\text { Ishkashim } \\
\text { Bazaar } \\
\text { (on credit) }\end{array}$ & $\begin{array}{l}\text { Purchase from } \\
\text { itinerant } \\
\text { traders in } \\
\text { Wakhan }\end{array}$ \\
\hline 1 kg of black tea (sir choy) & $80-90$ & 100 & 150 \\
\hline 1 kg of vegetable oil (tel) & $45-50$ & 50 & 100 \\
\hline 1 tin of "American oil" (2.7 kg) & 200 & 250 & 200 \\
\hline 1 ser of wheat & $40-60$ (seasonal) & $50-70$ (seasonal) & 120 \\
\hline 1 ser of salt (namak) & $20-25$ & 30 & 300 \\
\hline 1 ser of rice (bras) & $150-160$ & $170-200$ & 20 \\
\hline 1 kg of beans & 25 & 10 & 5 \\
\hline 1 piece of soap (zabun) & 7 & 2 & \\
\hline 1 matchbox & 2 & & \\
\hline
\end{tabular}

Note: Here we enquired only about goods which are purchased and consumed in Wakhan, sugar and cigarettes, onions, vegetables and fruit, and other items are available in Ishkashim, but are generally not purchased by customers from Wakhan

Source: own interviews in July 2003 
The further businessmen enter the valley and come to the houses of their customers the higher the prices grow. The lack of transport - from the central valley it is a five day donkey trip to Ishkashim bazaar -, the lack of price worthy shops within Wakhan - only a few so-called household shops exist in Qazideh with very small profit margins, and a small bazaar run by external businessmen with high prices operates in Khandut - force the Wakhi and Kirghiz to appreciate the services of the itinerant businessmen who come to their villages. The customers know that they pay overrated prices, but their seems to be no option, at least for the poor. A few households use their camels for the transport of bulky goods such as wheat flour all the way to Yamit, Pigash, Kurut and even to Sarhad-e Wakhan. But thy use these means for their personal needs alone. No cooperative effort has been started to encourage farmers to pool their purchases in Ishkashim bazaar and to gain higher profits from their agricultural products that way by paying lower prices for the goods bartered. There is scope for much improvement in this field which seems to be more advantageous to the saudegar than to the farmer and animal husbander (Table $4 b)$.

Table 4b: Purchase of agricultural commodities in exchange with bazaar goods by Ishkashim vendors and itinerant businessmen from Wakhi and Kirghiz (in Afghani and wheat units)

\begin{tabular}{|c|c|c|c|}
\hline Commodity & $\begin{array}{l}\text { Ishkashim Bazaar } \\
\text { (cash purchase) }\end{array}$ & $\begin{array}{l}\text { Ishkashim Bazaar } \\
\text { (sale of the same by } \\
\text { the shopkeepers) }\end{array}$ & $\begin{array}{l}\text { Barter with } \\
\text { itinerant traders } \\
\text { in Wakhan }\end{array}$ \\
\hline 1 ser of wheat & $45-50$ & & \\
\hline 1 fat-tailed sheep & $2000-2500$ & $2500-3000$ & 10-15 ser wheat \\
\hline $\begin{array}{l}1 \text { medium-sized sheep } \\
\text { or goat }\end{array}$ & 1500 & $1700-1800$ & 10 ser wheat \\
\hline 1 yak (one-year-old) & & & 10-15 ser wheat \\
\hline 1 yak ( 5 to 6 years) & & & 60 ser wheat \\
\hline $1 \mathrm{cow}$ & & & 20-25 ser wheat \\
\hline 1 ox & & & $20-40$ ser wheat \\
\hline 1 horse-cover (jhül) & $1000-2000$ & & \\
\hline 1 ser qurut & $\begin{array}{r}4-5 \text { ser wheat or up } \\
\text { to } 400 \text { Afghani }\end{array}$ & 500 & \\
\hline 1 ser butter (rugbun) & $\begin{array}{l}12 \text { ser wheat or up } \\
\text { to } 800 \text { Afghani }\end{array}$ & 1000 & \\
\hline 1 coarse carpet (palos) & $1100-1200$ & 1500 & \\
\hline
\end{tabular}

Source: own interviews in July 2003

Traditionally the Wakhi had more exchange with their Kirghiz neighbours and shared the business of bartering grain for animal products (Table 4c). But even at those times the local population was quite dependent on itinerant traders from Badakhshan and elsewhere for the purchase of clothes, tea and other consumer goods (Fig. 3). The present situation is characterized by production deficits in all fields: crop production and livestock-breeding. Consequently the high prices of external businessmen have an even more detrimental effect on the local economy and deprive the poor of their last resources. Therefore quite a number of households cannot afford to eat bread for several months and has to depend on the collection of any kind of "green plants" (lakb) mainly from the mountains until the next harvest is brought in. In July more than a quarter of the household had run out of grain stocks already while the next harvest was still two 
months away. To alleviate this constrained situation the food-for-work programme of Focus (mentioned above) was more than welcome in times of hardship.

Table 4c: Exchange of commodities between Wakhi and itinerant businessmen and between Wakhi and Kirghiz (in wheat units)

\begin{tabular}{|c|c|c|}
\hline Commodity & $\begin{array}{l}\text { Exchange between } \\
\text { Wakhi and Kirghiz }\end{array}$ & $\begin{array}{l}\text { Barter with itinerant } \\
\text { traders in Wakhan }\end{array}$ \\
\hline 1 fat-tailed sheep & 12 ser wheat & $10-15$ ser wheat \\
\hline 1 medium-sized sheep or goat & & $10 \mathrm{ser}$ wheat \\
\hline 1 yak (one-year-old) & & $10-15$ ser wheat \\
\hline 1 yak ( 5 to 6 years) & & $60 \mathrm{ser}$ wheat \\
\hline 1 cow & & $20-25$ ser wheat \\
\hline $1 \mathrm{ox}$ & & $20-40$ ser wheat \\
\hline 1 horse-cover $(j b \ddot{u})$ & $15-80$ serwheat & \\
\hline 1 ser qurut & 4 serwheat & \\
\hline 1 ser butter $(r u g b u n)$ & $8-12$ ser wheat & \\
\hline
\end{tabular}

Source: own interviews in July 2003

On the other side of the social scale we find three successful businessmen from Wakhan who have managed to learn from the external saudegar how to make profits. Muminbhoy from Tapc (near Babtangi) and Ramazonbhoy from Pigash have made a substantial wealth from big herds of livestock. They sell regularly about 200 and more animals per year. Both have succeeded in combining their livestock production and sale with the purchase of goods in favourable markets(a third person - Buribhoy from Yamit - does this on a smaller scale). Thus they purchase sheep from local farmers and Kirghiz nomads and drive them down the valley to the urban centres. Both have succeeded within the last year to purchase a Russian Ural truck to participate in the business of bringing saudegar and their goods up the valley, provide transport to local people and to construction projects. They have proved that more of the profits in the exchange and barter economy could be realized within the Wakhan community.

\subsection{Tourism and trophy-hunting}

"Modern" forms of income-generating in remote mountain regions are often linked to service industries in case the mountains are of any attraction to visitors. This is very much the case in Wakhan and the Afghan Pamirs. In this field the region has gained quite some experiences when mountaineering expeditions visited Wakhan in the 1960s and 1970s. For the villages of Qazideh, Wark, Keshnikan, Ptukh and a few others portering and support services became a seasonal source of income. This source dried up in the late 1970s and in 2003 the first mountaineering expedition (since 28 years) visited Qazi Deh. ${ }^{5}$ The impact is not really felt of this source of income and the expectations of the local leaders are not very high towards tourism in general.

\footnotetext{
${ }^{5}$ ) Camouflaged as a training exercise - in fact only four persons were hired to accompany the mountaineers - the Qazi Deh valley as the approach route posed a major problem for access. The Qazi deh valley is basically the only place in Wakhan with landmine fields. As the expedition group would not afford to cover the expenses for demining the responsible person for putting the mines was found and led the group around.
} 
Trophy-hunting was well-known in Wakhan due to the seasonal operation of King Zahir Shah's hunting camp in the Great Pamir (Pamir-e Kalan). The location for the regal hunting lodge was the Tolibai valley where King Zahir Shah had hunted a major Marco Polo ram in the late 1950s. Only in 1968 permission was granted for the first overseas safari tours operator to hunt wild sheep in the valley (Petocz 1973: 25,1978b: 1). As early as in 1973 four valleys of the Great Pamir were identified as game reserves: Sargaz, Tulibai, Manjulak and Abakhan (Petocz 1973). These valleys were taken away as grazing grounds from the local Wakhi shepherds and reserved for trophy-hunting organized through A fghantour. Four Wakhi were provided jobs as overseers of grazing and hunting restrictions. Additional small measures could not cover the loss of grazing grounds to the Wakhi shepherds and the imposition of restrictions created a constant source of dispute.

Due to some opposition from the Kirghiz leader Rahman Qul trophy-hunting was not brought into the Kirghiz grazing grounds in the Great and Little Pamir. Tourism planning aimed at introducing trekking and wildlife viewing. Those were the activities and plans of the 1970s. Since then a major break-down of all tourism activities has occurred and no infrastructure is left. Nevertheless, given the attraction of Wakhan and the Afghan Pamirs to European travellers tourism in appropriate forms could be rejuvenated. The constraints and the potential conflicts between pasture utilization for domestic stock and wild animals needs thoughtful consideration. Any kind of additional source of cash income with all its fringe benefits to drivers, porters, and other staff could help in this region.

\subsection{NGO activities at present}

There are a limited number of NGOs active in Wakhan Woluswali. The predominant perception of the local people is that Focus which is often mixed up with AKDN and vice versa is a monopolizing organization. Several of our interview partners stated that they are not satisfied with scope and range of activity fields of Focus/AKDN, they fear at the same time that other organizations are put off through their presence. The following organizations are presently working in Wakhan:

- Focus Humanitarian Aid: Focus started to work as a relief organization in the border districts of northeastern Afghanistan. Since 2000 they have tried to shift from sole relief work and humanitarian aid distribution to development work by improving infrastructure and agricultural extension and production. Presently Focus is restructuring its activities to the field of infrastructure improvement, strongly visible in the food-for-work programme along the Wakhan Road. In the Kirghiz community areas they still continue the distribution of humanitarian aid in the form of basic food and clothing. At least this was the case after the devastating effects of late snowfall in spring became perceivable.

- AKDN: The Aga Khan Development Network is active in their usual fields: They are constructing two clinics (at least the physical buildings in Ishkashim and Khandut) and three schools (Futur, Qazideh, Khandut) on the basis of food-for-work. AKDN has taken over from Focus recently the agricultural package which concentrates on "natural resource management" (NRM) and rural development. Besides agricultural extension work mineral fertilizers such as urea and DAP, wheat and vegetable seeds, fruit saplings and fodder crop seeds are distributed (donors for the Wakhan programme are GTZ and Euronaid). As one of the few female related programmes they have introduced a package called "training of women by women" for setting-up kitchen gardens in the villages. Information provided by Mamad Amir, District Manager AKDN NRM. AKDN is instrumental as well in the milk pack distribution in schools which was executed during the last two months. 
- UNICEF: Unicef is active in the uplift of the education system by providing tents as temporary or emergency replacements for the dilapidated local school buildings. In addition they support the availability of teaching materials and satchels.

- ORA: Orphans, Refugees and Aid International have started with Dr. Alex Duncan and his wife Eleanor a health training campaign for Wakhan. Local women are trained in traditional birth attendance and other hygienic practices. Medical services and check-ups are provided as well. For the first time since long a professional medical doctor is present in Wakhan for a longer period.

- MSF: Médecins sans frontière are based in Ishkashim where they jointly operate a clinic with the Ministry of Public Health. In August-September a second clinic is to be opened for TB patients. Sometimes a MSF team visits the valleys of Zebak, Wakhan, Gharan.

\section{Conclusions and recommendations}

In the previous chapters deficits and shortcomings in a number of fields have been highlighted. In the following we would like to emphasize on certain aspects which need further consideration:

\section{- Infrastructure development}

- Road infrastructure: The food-for work programme was a good beginning but needs a continuation which is not backed by donors at the moment. The scope for improvement is quite substantial and the difficult sections of the road need to be tackled in the future, especially culverts and small bridges are of eminent importance. The road projects functioning as a continuation beyond Sarhad-e Wakhan (towards the Little Pamir) or as a link road (towards the Great Pamir) would be of importance if a road link and a subsequent infrastructure integration of the Kirghiz pastures into the administrative and supply structure of Wakhan Woluswali is envisaged. The road into the Great Pamir valleys would as well be a major infrastructure requirement for trophy-hunting and trekking tourism in this least accessible part.

- Electricity: The establishment of decentralised hydro-electrical power generators are feasible in many places. Electricity ranges high on the priority list of many people, but only the small group of well-off people could enjoy this "luxury" in the immediate future. The attraction to electricity is somehow guided by the impression that it would come "for free" and thus reduce the regular costs for lamp oil, kerosene etc. Great expectations are linked to electricity for the winter period (light and heating) although power generation in some locations could be significantly hampered due to non-availability of running water in the cold season (reduced to none glacier-melt, no snow-melt).

- Drinking water: The supply of clean drinking-water is of prime importance for the general health situation and would be a major improvement of the living conditions. Taking into account the present rates of child and mother mortality and the prevalence of water-borne diseases the establishment of a piped water system at least in the large villages could have a tremendous impact on the social amenities. The implementation would be a feasible package through food-for-work programme as the villagers could be involved in construction work at their door-step. A diagnostic survey would be required to define potentials and degrees of need.

\section{- Agriculture}

- Crop-farming: The traditional cultivation system within Wakhan emphasizes the production of bread crops of some variety (wheat, barley, millet, peas, pulses and beans) which all are utilized for the baking of the staple-food which comes basically as unleavened flat breads prepared in a tandoori-like open fireplace in the centre of the house. 
Bread comprises together with salted milk tea (and if available other milk products) the staple diet of Wakhi and Kirghiz alike. It is not surprising that wheat is the prime category of exchange and calculating prices.

As landholdings are rather small - although it was surprising to observe that landholdings were varying quite a bit within the villages - and will become smaller from generation to generation if no new land is cultivated or people outmigrate to found new settlements, there is dire need for extending the physical agricultural infrastructure in the form of newly cultivated village lands. During our enquiries it was quite surprising to learn that there is in many locations cultivable land, but that due to a number of reasons no effort has been started by the village community or any stakeholder to build new irrigation channels and develop terraced fields. This again would be a appropriate scheme for foodfor-work projects or for an approach as shown by the AKRSP in Northern Pakistan through their system of village organizations (VO). A VO was formed on the basis of a grant given to them - mainly for the construction of an irrigation channel - and from that grant the work on the construction site was remunerated from which again some funds were attributed to a savings account of the VO. Land development was then again under the authority of the VO.

Nevertheless there is ample scope for improving the seeds, for exchange of seeds between villages, but as well for the introduction of faster growing and more hardy varieties from outside. Fertiliser is generally only used in the form of animal manure, farmers who apply urea and DAP do this because they are supplied with it through an NGO. Substantial yield increases are feasible, only the cash for investing in it are lacking.

There is scope for further promotion of potato cultivation although there are some dietary reservations as potatoes do not fit into the "bread diet" and one has to keep in mind that traditional foods are prepared with limited energy requirement in form of fuel (animal dung, seabuckthorns and firewood) while potatoes require significantly higher amounts for that.

Experiments with vegetable seed fruit tree saplings distribution have begun in the AKDN NRM programme. As only a limited number of villages is covered yet - they have organized the whole valley into clusters with an appointed Village Extension Worker (VEW) in charge - there is still ample space for further packages and interventions. The replacement of the Latbyrus sativus (krosh) variety of pulses which causes lathyrism when consumed in too high quantities on a regular basis and/or if individual predispositions prevail (locally affected people are described as having contracted "polio") is an important aim as it would easily be feasible to introduce another crop with similar nutritional properties and earlier ripening (buckwheat (Fagopyrum esculentum or tataricum) and/or bean/pea/pulses varieties such as mungo beans, red and white beans).

In some locations the availability of winter fodder and the production potential for fodder crops needs to be looked into. The spring of 2003 severely affected the livelihoods of mountain farmers as the winter fodder was in short supply and the sowing of the springcrops in this single-cropping (ek-fasli) area was extremely late. Therefore it is feared that in autumn 2003 not all crops will be ready for harvesting and that a serious shortage of food supplies results. This is not an annual feature of the region, but it is within the normal span of variation of agro-ecological conditions in this part where the cultivation period is limited by altitude, exposition and the occurrence of infamous strong winds (bad-e Wakban) from autumn to spring.

- Livestock-keeping: In general the agricultural rule in marginal mountain areas that crop-farming is more secure though providing lower returns and that livestock-keeping is more risky but offers potentially higher profits (if successful) holds true here as well. The 
Wakhi reduce their risk by following combined mountain agriculture while the Kirghiz nomads are playing the risky game. As very experienced animal breeders they have proved over long periods that they could be quite successful. With lacking certain exchange opportunities their success in recent years was rather marginal. They suffered substantially from animal losses in spring of 2003 when late snowfall killed substantial parts of their flocks and limited the available fodder base. Consequently Focus agreed to supply them again with humanitarian aid during this year although they stopped that for Wakhi farmers (who are in great need as well). Regarding the socio-economic situation of the animal husbanders the local leader Shah Ismael put his estimation that way: "The worst-off people are the Kirghiz of the Great Pamir. They are suffering from are living in a remote location and having practically no exchange partners as the border to Tajikistan is basically closed, in the intermediate position are the Wakhi farmers with all their limitations, while the Kirghiz of the Little Pamir manage the top position due to their exchange relations with Pakistan." He emphasized very much the need for exchange as the Kirghiz do not engage in any cultivation and are completely depending on bartering their staple food wheat flour - for their livestock products. Within the community some Wakhi of the upper valley give their animals to Kirghiz nomads for custody during the cold season, some Wakhi from the upper villages work for Kirghiz as shepherds.

The livestock sector could be significantly improved if livestock diseases such as foot-andmouth disease (which reduced herds in some villages tremendously) could be controlled or mitigated through the provision of veterinary services. It is strongly recommended to look into this sector more closely as the pasture resources of Wakhan Woluswali are the major natural asset of the region and have proved earlier on to be very productive.

\section{- Education and health}

- Education facilities are at the lowest possible level as stated above. A combined effort of more NGOs could improve the physical structure, the availability of teaching materials, the quality of teaching etc. At the moment there are no signs of significant change in this field although meagre but insufficient attempts have been initiated.

- Health: The ORA programme for Wakhan comes as a blessing in disguise, nobody would have expected to have an expatriate professional medical doctor residing in the heart of the valley. In combination with AKDN's and MSF's activities from Ishkashim and within Wakhan there is some improvement. If they could manage to reduce the influence of self-appointed "doctors" who as itinerant traders buy cheap, out-dated and/or inappropriate medecines in the urban bazaars and bring them to Wakhan and offer them at comparatively high prices to the needy, then a substantial improvement would be achieved and funds saved for other approaches.

\section{- Mobility, migration and non-agrarian income generation through wages and salaries}

Mobility will remain an important strategy to mitigate certain production deficits and might increase when conditions in the urban centres of Badakhshan and further cities down the road will stabilize. For a high mountain region this is a sensible strategy for "security enhancement". But the extremely low wages generated do not improve the livelihoods of the households within Wakhan and will have no significant impact on the cash economy there.

\section{- Exchange economy and entrepreneurship}

Major losses of Wakhi and Kirghiz are related to their weak position towards any kind of external businessmen either in Ishkashim Bazaar or with itinerant traders (Fig. 3). As the range of goods required in the households is so limited (wheat, tea, salt, vegetable oil, rice, 
beans, soap, matchboxes) it would be easily implementable at nominal costs to support the foundation of a cooperative society which would purchase those goods at favourable prices in Faizabad or Taloqan, organize bulk transport from there to Ishkashim and further to four distribution centres within Wakhan: Qazideh, Khandut, Qala-e Panja and Sarhad-e Wakhan. The latter would be the distribution point for the Kirghiz of Little Pamir while Qala-e Panja would function for the Kirghiz in the Great Pamir. Small storescum-shops and the employment of trustworthy and competent store-keepers in these "fair-price-shops" would be required. With such an approach the overpriced goods of itinerant traders could become more reasonable and consequently local products would gain in exchange value. A second step could concentrate on the marketing of locally produced livestock and their products. Marketing options within Badakhshan and towards other urban markets need to be explored. Local shepherds who previously supplied their services to itinerant businessmen would know about marketing outlets although this is the more complicated part of improving the returns from local production.

The experiences of the successful local businessmen could be utilized, they and their transport capacities could be involved in this simple but effective scheme.

\section{- Tourism and trophy-hunting}

The tourism potential has been highlighted above and the potential for ecotourism and trophy-hunting needs to be explored further. The preconditions for these service industries are prevalence of personal security, safeguarding access (permits, transport, fuel supply) and in a combined effort trans-border facilities for round-trip arrangements (Pakistan-A fghanistan-Tajikistan-China).

Due to previous experiences with trekking, mountaineering and trophy-hunting within Wakhan there are ample points for reconnecting to those with adapting the strategy to present-day conditions.

\subsection{Wakhan Woluswali}

In summary the above conclusions and recommendations are applicable to the whole of Wakhan Woluswali, i.e., the Wakhi villages with their system of combined mountain agriculture, their limited cash flow and entrepreneurship on the one hand, and the Kirghiz nomads with their system of mountain-related mobile animal husbandry on the other. Any development effort has to take into consideration these two basic strategies of utilizing and exploiting the natural potential of the region. Because of poor other skills, poor education standards and professional training emphasis needs to be put on the significant uplift of grain and livestock production to cover basic needs on a subsistence level but to provide at the same time market products for necessary bartering (cf. Fig. 3).

Nobody obviously had any knowledge about attempts to exploit other natural resources such as minerals, semi-precious and precious stones. This was surprising as the world-renowned Lapis lazuli mine of Sar-e Sang (Kokcha), the spinell (lal-e badakhshan) mines of Gharan, the gold dust washing on the banks of glacier-melt water-fed rivers and potential marble quarries of Langar are not that far away.

In general, the impoverished groups have grown significantly in the last quarter century, more than three quarters of the society belong to vulnerable groups due to the size of their landholdings, livestock herds (if there is livestock at all) and household circumstances. Special vulnerable groups are widows with no grown-up male workforce in their households. Although a system of neighbourhood support services (keriyar) exists many people cannot afford to 
participate because of lack of own household resources. Another group of vulnerable people includes those households where the workforce is diminished by suffering from "polio" (due to krosh consumption) and other diseases. A third group to be distinguished is that one which consists of those households where major assets were lost due to opium (teryok) consumption of one or more household members. This phenomenon applies especially to Kirghiz households where during the last quarter century opium consumption has substantially increased.
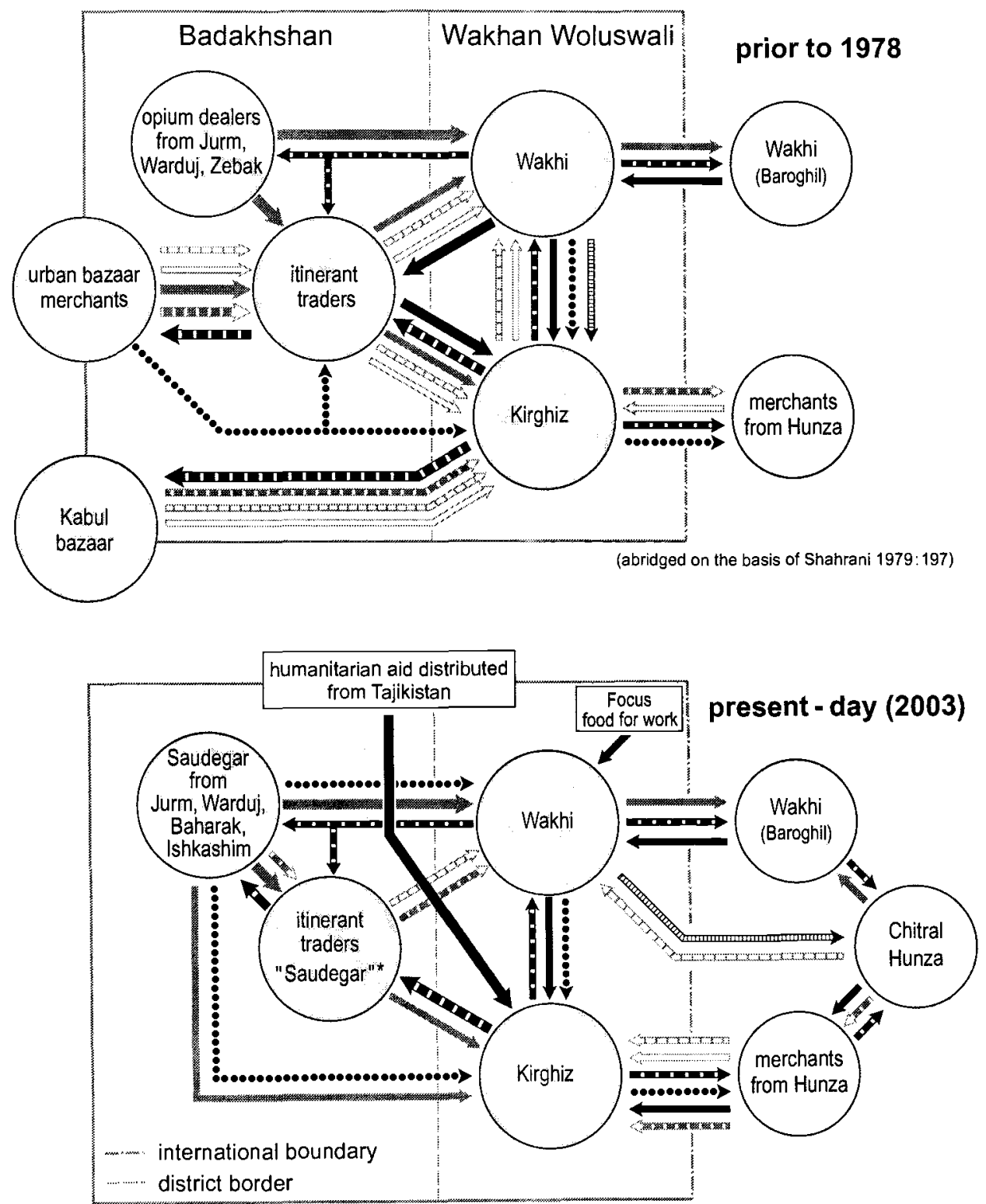

Design based on fieldwork 2000 and 2003: H. Kreutzmann

goods imported into Wakhan

goods and services available in Wakhan

$\begin{array}{ll}\ldots & \text { opium } \\ & \text { cloth } \\ & \text { consumer goods }\end{array}$

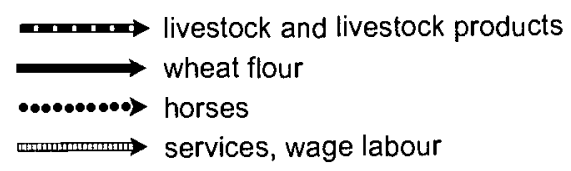

* from Kabul, Paghman, Taloqan, Qunduz, Faisabad, Jalalabad

Fig. 3: Comparison of exchange relations of Wakhi and Kirghiz over time 


\subsection{Position of the Kirghiz}

The situation in the Kirghiz areas of the Great and Little Pamir (cf. Fig. 1) has some special features which need to be addressed here when strategies for poverty alleviation are in focus. There is no school, no shop, no health worker, not veterinary specialist in the Kirghiz areas at present. The Kirghiz are totally dependent on the supply of bread flour from outside as they do not practice crop farming. At those high altitudes (above $3500 \mathrm{~m}$, mainly above $4000 \mathrm{~m}$ ) there would be not much potential for grain crops either.

This situation which looks bleak is reflected in the discussions about resettlement in Kyrgyzstan which were prominent in 2000 during our visit with Abdurrashid Khan (see App. 2). This option has now been ruled out and is no option anymore because of different reasons, the strongest might be the fading to non-existing interest of the Kyrgyzstan government at present and probably in future as well to attract any settlers. But there are some local reasons too, including those of giving up valuable pastures for good, loss of certain degrees of freedom and some sense of belonging to Afghanistan although residing in the remotest corner.

In former times the Kirghiz showed a strong link to the King's court and the bazaar of Kabul by sending once a year the famous "winter caravan" to Kabul (cf. Fig. 3) where they did the marketing of their livestock and related products. The herd size was significant and the business brought quite some cash to Wakhan. They earned that much from this market that even some Wakhi households found seasonal and permanent employment in the Kirghiz grazing grounds (cf. Shahrani 1979). With this they have proved that their economic approach is feasible and valuable. How to improve this situation nowadays? In the mid-1970s Kirghiz nomads of the Little and Great Pamirs owned 38600 sheep and goats, 3544 yaks, 318 horses, and 83 camels (Shahrani 1979: 177). In comparison, a quarter century later the total number is much less (Table 5). One could argue that this proves only that the carrying capacity of the Pamirs is not fully utilized. But when we compare that there were about 333 households comprising a population of 1825 persons living there in the mid-1970s with the population in 1999 with 237 households and 1264 persons (in 2003 approximately 250 households), then we can calculate that in equal terms there should be about two thirds of the animals. But Table 5 significantly shows that horses and camels are there in adequate numbers as they are undisposable of because of transport requirements, but the number of sheep and goats is only one third of what it should be and the number of yaks just two thirds when compared with previous times. This is strong proof for our observation that market relations have been severed and constrained - thus sheep and goats as the prime market product are there only in small numbers - but the domestic livelihood shows shortcomings as well because the size of yak herds - they are predominantly bred for home consumption and utilization (milk, meat, dung, hair, tails) - has significantly been diminished. We can conclude that the Kirghiz in the Afghan Pamirs are worse off than they could be and that there is scope for improving their livelihoods.

Table 5: Comparison of herd sizes among the Kirghiz in mid-1970s and 1999

\begin{tabular}{|l|r|r|r|}
\hline Animals & mid-1970s & \multicolumn{1}{|l|}{1999} & $\begin{array}{l}\text { Comparison of both } \\
\text { (percentage ) }\end{array}$ \\
\hline Sheep and goats & 38600 & 8836 & 22.9 \\
\hline Yak & 3544 & 1424 & 40.2 \\
\hline Horses & 318 & 159 & 50.0 \\
\hline Camels & 83 & 91 & 109.6 \\
\hline
\end{tabular}

Source: own calculation based on data derived from Shahrani 1979: 177 and Focus survey Aug-Sep 1999 
How to better the living conditions. Since 1997 there have been some experiments of organizing trade fairs between Kirghiz from Murghab (Pamirski Post) District in Tajikistan and Afghan Kirghiz. On Aug, 16, 2003 the next trade fair takes place in Ghundjibhoi in the border area between the Little Pamir and Kizil Robat. Goods to be exchanged are: wheat flour, household goods, clothes and diesel from Tajikistan (all goods are taxed by the district authorities) against live animals (fat-tailed sheep) from Afghanistan. The Kirghiz from there are renown for their good trading skills by their neighbours from Tajikistan. Similar trade fairs have taken place west of Lake Zor Köl between Alichur Pamir and the Great Pamir of A fghanistan. Out of some reasons we could not establish these trade fairs ceased to exist although there is more need of exchange in this part of the Pamirs. These trade fairs could help in the exchange of experiences in livestock breeding as many of the privatised animal husbanders of Murghab District are still in the process of (re-) learning the practices of their grandfathers from the time before collectivization.

The enhanced exchange between Murghab District and the Afghan Pamirs has certain advantages beyond pastoral knowledge dissemination. Dearly required supplies and necessary consumer goods (wheat, salt, tea, vegetable oil, pulses and beans, matchboxes and other goods) could easily be transported from Murghab to the Afghan Pamirs as cost-effective motorized access is possible and links to a number of grazing grounds exist. As long as the Wakhan road is not extended which is unlikely in the near future - to the Afghan Pamirs this option could overcome the bottleneck situation in which the Kirghiz are dwelling and suffering at present. All sides could profit from this trans-border exchange as cash flow is little on either side of the border. For humanitarian aid distribution permission was previously granted to use these supply lines.

The lack of any health and education institutions and the principle difficulty to establish such institutions in a nomadic environment where mobility and scattered tent encampments are the rule become the driving factor for the suggestion to school Kirghiz children either in a boarding school outside Wakhan where quality teaching is guaranteed or in a boarding school of the type which is established and rehabilitated in Shaymak through ACTED (sponsored by SDC). A selected number of Kirghiz pupils would profit from this opportunity of dearly required education for their community.

A similar approach would apply to access to health facilities. As long as the health infrastructure in Wakhan Woluswali is concentrated at far off locations at the entrance of the valley (Ishkashim is more than $250 \mathrm{~km}$ away from the Pamirs) or in the centre (Khandut, Qala-e Panja) an approach to Tokhtamish and/or Murghab in Tajikistan should be possible at least in emergency cases. Even a mobile medical unit should visit the Kirghiz yurt encampments for a survey of the health situation. During our visit in 2000 we heard about undiagnosed strange diseases which caused female household members to die. The only medicine available and applied was opium, but with little to no success.

In general: a more pragmatic approach is required to overcome orographic and political boundaries if the uplift and well-being of the people residing in this part of the country are of any concern. The Kirghiz have proved in the past that they provided valuable services to the Afghan Government in controlling and securing the international boundaries at nominal cost.

\subsection{Potential for development and stakeholders}

Who are the persons who need to be involved in all activities to be implemented in Wakhan Woluswali?

- First of all Shah Ismael of Qala-e Panja needs to be mentioned who has the capacity to formulate the concern of the residents, to approach the necessary institutions and who can gather 
and convince substantial groups of people for communal efforts and undertakings. In addition, the influence of Shah-e Langar from Qazideh should not be neglected and side-lined.

- The leader of the Kirghiz community, Abdurrashid Khan of Kara Jilga, has to be involved in all affairs concerning the Kirghiz. His advisor is Nioz Ali Patuwani, a Wakhi refugee from Khandut who left because of political disputes from there. He is supporting Abdurrashid Khan as a scribe (munshi) or secretary. Besides Haji Osmon, Effendi and some other influential Kirghiz personalities need to be consulted. Within the Kirghiz community there seem to be two persons who are literate in Cyrillic script, one is named Rahim, s/o Abdul Jalil, none was reported to be literate in Dari. We had no opportunity to talk to them.

- The employment of professionals from other regions in Badakhshan for any kind of post and project (manager, engineer, etc.) shows the bad state of education in Wakhan, Nevertheless, the successful businessmen of Wakhan such as Munimbhoy from Tapc, Ramazonbhoy from Pigash, and Buribhoy from Yamit need to be incorporated in the implementation of infrastructure projects. Unfortunately, we did not meet any commendable teachers although there might be some personalities to take into consideration as well.

Among the commanders the services and concern of the local commander Fateh Ali Shah (originally from Qala-e Panja) are of importance as he is well versed with local conditions and constraints and would be able to establish contacts to experienced and professional farmers and animal husbanders.

There will be other personalities to be identified which could not be met and contacted yet.

\section{References}

Curzon, G. N. 1896: The Pamirs and the Source of the Oxus. In: The Geographical Journal 8, S. $15-54,97-119,239-264$

Dor, R. \& C. M. Naumann 1978: Die Kirghisen des afghanischen Pamir. Graz.

Duncan, A. \& E. Duncan 2002: Report of Survey of Wakhan District, Badakhshan Province, Afghanistan. Prepared for ORA Peshawar

Ehlers, E. \& H. Kreutzmann (eds.) 2000: High mountain pastoralism in Northern Pakistan (= Erdkundliches Wissen 132). Stuttgart: Steiner

Felmy, S. 1997: The voice of the nightingale. A personal account of the Wakhi culture in Hunza. Oxford: Oxford University Press

Finnconsult 1976: Socio-economic Survey of Badakhshan, Volume I: Main Report; Volume III Sectoral Reports (hrsg. von The Republic of Afghanistan. Ministry of Planning). Kabul.

Focus 1998: Stepping out of poverty. A strategy for poverty alleviation in Badakhshan, Afghanistan. Joint mission of AKF and Focus to Afghan Badakhshan in June 1998.

Focus 1998: Afghan Badakhshan: Background and discussion paper.

Gordon, T. E. 1876: The roof of the world, being the narrative of a journey over the high plateau of Tibet to the Russian frontier and the Oxus Sources on Pamir. Edinburgh.

Kreutzmann, H. 1996: Ethnizität im Entwicklungsprozeß. Die Wakhi in Hochasien. Berlin

Kreutzmann, H. 1998: The Chitral Triangle: Rise and Decline of Trans-montane Central Asian Trade, 1895-1935. In: Asien-A frika-Lateinamerika 26 (3), pp. 289-327 
Kreutzmann, H. 1999: Water as a development factor in semi-arid mountainous areas of settlement. Systematic approach and development potential. In: Natural resources and development 49/50: Focus: Water - the lifeline of our future, pp. 99-116

Kreutzmann, H. 2000a: Improving Accessibility for Mountain Development. Role of Transport Networks and Urban Settlements.

In: Banskota, M., Papola, T. S. \& J. Richter (Hrsg.): Growth, Poverty Alleviation and Sustainable Resource Management in the Mountain Areas of South Asia. Proceedings of the International Conference held from 31 January - 4 February 2000 in Kathmandu, Nepal, pp. 485-513

Kreutzmann, H. 2000b: Animal Husbandry in High Asia. Yak-keeping at the Upper Pastoral Limits. In: Miehe, G. \& Zhang Yili (Hrsg.): Environmental Changes in High Asia. Proceedings of an International Symposium at the University of Marburg, Faculty of Geography $29^{\text {th }}$ of May to $1^{\text {st }}$ of June 1997 under the auspices of the Unesco. Marburg/Lahn (= Marburger Geographische Schriften 135), pp. 361-375

Kreutzmann, H. 2000c: Wakhan - Weltpolitische Wirkungen zwischen Pamir und Hindukusch. In: Geographische Rundschau 52 (1), pp. 60-63

Kreutzmann, H. 2001: Überlebensstrategien der Kirgisen Afghanistans. Nomaden auf dem Dach der Welt. In: Geographische Rundschau 53 (9), pp. $52-56$

Kreutzmann, H. 2003: Ethnic minorities and marginality in the Pamirian knot. Survival of Wakhi and Kirghiz in a harsh environment and global contexts. In: The Geographical Journal 169 (September 2003, in print)

Petocz, R. G. 1973: Marco Polo sheep (Ovis ammon poli) of the Afghan Pamir. A report of biological investigatins in 1972-1973. n. p.

Petocz, R. G. 1978a: Report on the Afghan Pamir. Part 1: Ecological Reconnaissance. Kabul.

Petocz, R. et al. 1978b: Report on the Afghan Pamir. Part 2: Biology of Marco Polo Sheep (Ovis ammon poli). Kabul.

Petocz, R. G. 1978c: Report on the Afghan Pamir. Part 3: Management Plan for the Big Pamir Wildlife Reserve. Kabul.

Polo, M. 1984: Il Milione. Die Wunder der Welt (Übersetzung von Elise Guignard aus altfranzösischen und lateinischen Quellen). Zürich.

Shahrani, M. N. 1979a: The Kirghiz and Wakhi of Afghanistan. Adaptation to Closed Frontiers. Seattle und London.

Shahrani, M. N. 1979b: Ethnic relations under closed frontier conditions: Northeastern Badakhshan. In: McCagg, W. \& B. Silver (Hrsg.): Soviet Asian Ethnic Frontiers. New York, S. 174-192.

Unidata 1992: Afghanistan. Badakhshan Province. A socio-economic profile. Kabul 


\section{Appendix 1: Itinerary of the Wakhan mission from Taloqan to Murghab}

\begin{tabular}{|c|c|}
\hline July 16 & $\begin{array}{l}\text { Arrival of Sabine Felmy and Hermann Kreutzmann in Taloqan, meeting } \\
\text { with logistical support group under Engineer Qahar and Haidar; } \\
\text { preparation for departure with Karimullah (interpreter) and M. Assef } \\
\text { (driver) in Talogan }\end{array}$ \\
\hline July 17 & $\begin{array}{l}\text { Taloqan - Faizabad: completion of the mission group after the arrival of } \\
\text { Letitia Millon, departure for Faizabad }\end{array}$ \\
\hline July 18 & $\begin{array}{l}\text { Faizabad: meeting with the governor, exchange of letters } \\
\text { departure for Baharak and Ishkashim: road blockage between Faizabad and } \\
\text { Ishkashim reqquires the hire of additional transport facilities }\end{array}$ \\
\hline July 19 & $\begin{array}{l}\text { Ishkashim: meeting with the deputy Woluswal in Ishkashim and with the } \\
\text { sub-commander Hafiz who issued the travel permit for the Wakhan } \\
\text { mission on authority of Ashur Beg, the commander of Ishkashim; } \\
\text { departure to Khandut: discussion with the acting Woluswal Mullah M. Jon } \\
\text { and the concerned commander Qadir Khan from Zardeu }\end{array}$ \\
\hline July 20 & $\begin{array}{l}\text { Khandut-Pekui-Qala-e Panja: Interviews on route to Qala-e Panja with } \\
\text { farmers and their household members in Pekui. } \\
\text { meeting in Qala-e Panja with the political and spiritual leader of Wakhan } \\
\text { Sha Ismael, participation in the foundation ceremony for the jamaat khana } \\
\text { (Ismailia meeting place and prayer house). } \\
\text { meeting and discussions with Dr. Alex Duncan and his wife Eleanor } \\
\text { Duncan who are working for ORA in a project in Wakhan aiming at } \\
\text { dissemenating health training to the villages, teaching of local health } \\
\text { workers in order to reduce mother and child mortality }\end{array}$ \\
\hline July 21 & $\begin{array}{l}\text { Qala-e Panja: interviews with the headmaster Aminuddin and teachers of } \\
\text { the secondary school; } \\
\text { enquiries with farmers and their household members about agricultural } \\
\text { practices, cultivation cycles, yield patterns, combined mountain agriculture } \\
\text { and its linkage to animal hsbandry, herd migration, production and } \\
\text { marketing }\end{array}$ \\
\hline July 22 & $\begin{array}{l}\text { Qala-e Panja-Kurut-Tapch-Kipkut-Marabar: interviews about agricultural } \\
\text { practices, livestock-keeping, social structure, development activities, market } \\
\text { and bazaar relations with farmers and their household members }\end{array}$ \\
\hline July 23 & $\begin{array}{l}\text { Marabar-Pikut-Qala-e Panja: Interviews and enquiries with farmers from } \\
\text { medium-well-off households in Kipkut } \\
\text { inspection of the irrgation system in Qala-e Panja, visit of tradesmen such } \\
\text { as blacksmiths, masons and carpenters who generate some additional non- } \\
\text { agrarian income with their skills }\end{array}$ \\
\hline July 24 & $\begin{array}{l}\text { Qala-e Panja-Urgund-Qazideh: Interviews with farmers, teachers and their } \\
\text { household members } \\
\text { Qazideh: meeting with Mamad Amir,District Manager of the AKDN } \\
\text { Natural Resource Management (NRM) project which has taken over } \\
\text { programme packages from Focus } \\
\text { meeting with Shah-e Langar, the spiritual and political leader of the } \\
\text { community in lower Wakhan, discussion of market relations and } \\
\text { development activities, priorities for action }\end{array}$ \\
\hline
\end{tabular}




\begin{tabular}{|l|l|}
\hline July 25 & $\begin{array}{l}\text { Qazideh-Ishkashim: continuation of discussions with Mamad Amir and } \\
\text { Shah-e Langar, visit of project sites in Qazideh } \\
\text { inspection of food-for-work distribution site for Futur and Qazideh; } \\
\text { Ishkashim: interview with Azmudin, team leader distribution Focus; } \\
\text { discussion with Syed Imran Khan from Baharak, Woluswal in Ishkashim, } \\
\text { about his future plans for Ishkashim; } \\
\text { visit of MSF office in Ishkashim: discussion with Erika Widmer about the } \\
\text { plan of opening a TB clinic by August-September } 2003 \text { and the general } \\
\text { health and nutritional situation in northeastern Afghanistan; } \\
\text { Ishkashim bazaar: comparison of market prices of Ishkashim bazaar, } \\
\text { interviews with businessmen and vendors }\end{array}$ \\
\hline July 26 & $\begin{array}{l}\text { Ishkashim-Murghab: crossing from Afghan to Tajik Ishkashim, journey via } \\
\text { Rajon Ishkashim and Langar across Khargosh pass into the Alichur Pamir } \\
\text { and finally to Murghab }\end{array}$ \\
\hline July 27 & $\begin{array}{l}\text { Murghab: evaluation of empirical material gathered, brainstorming about } \\
\text { the compilation of the information for the mission report, distribution of } \\
\text { responsibilities and group discussion }\end{array}$ \\
\hline July 28 & $\begin{array}{l}\text { Murghab-Shaymak-Kizil Robat-Murghab: enquiries about the exchange } \\
\text { relations between Kirghiz of Tajikistan and Afghanistan, inspection of } \\
\text { supply situation and discussion with Obaidullah and the local security chief } \\
\text { about potentails, chances and bureaucratic limitations within the border } \\
\text { trade context }\end{array}$ \\
\hline July 29 & \begin{tabular}{l} 
End of the Wakhan mission and split-up of group \\
\hline
\end{tabular} \\
\hline
\end{tabular}

\section{Acknowledgements}

We are particularly grateful for the logistical support from ACTED offices in Dushanbe, Kabul, Murghab and Taloqan. Special thanks to Engineer Qahar and his team for constant support, Karimullah for interpreting and M. Assef for safe driving and mastering the swollen glacier rivers and challenging roads. 
Appendix 2: English translation of an article published in Frankfurter Rundschau No. 258 of November 6, 2000, p. 9

\section{HARD TIMES ON THE ROOF OF THE WORLD}

The forgotten Kirghiz nomads of Afghanistan's Pamir mountains

\section{By Hermann Kreutzmann}

Tajikistan, on the Afghan border - The Russian-made trucks laden with wheat flour creep their way along the road that stretches across the eastern Pamir Mountains. The Tajiki border guards and the KGB commander in Murghab have decided to allow humanitarian goods to be distributed among the Kirghiz people in Afghanistan's Little Pamir area.

The convoy starts moving away from the Russian outposts that have been here for 110 years. It rolls along a metal fence that marks the "system", heading for the last checkpoint before the border with Afghanistan. From here on out the trucks are accompanied by four Russian officers who lead them into the "system": the quasi-demilitarised zone between China and Tajikistan. Here, at the outer tip of the Wakhan corridor, four nations that confronted each other throughout the Cold War meet: China, the former Soviet Union, westward-leaning Pakistan and the buffer state of Afghanistan.

Global political events have left deep wounds even in this remote corner of central Asia. Humanitarian relief became necessary due to the failure of Tajikistan to respond to requests from the Kirghiz nomads of the Great and Little Pamir regions to help them cushion the impact of severe supply shortages. Tajikistan was hardly in a position to help the nomads. Being poor itself, it can't even feed its own population without foreign aid. For three years the organisation Focus International has delivered basic supplies to the nomads once or twice a year.

The Afghan border is marked by a simple post; this "inofficial"; border crossing has no guards or barriers. Waiting for the convoy not far from the border is a delegation of Kirghiz people with their leader, Abdurrashid Khan. Focus International has gathered information and compiled lists of the needy in advance. Over the next two days, nomads will be arriving with their yaks and tow ropes from camps across the entire Pamir region to pick up rations for their yurt communities. The food is distributed at an altitude of 4,000 metres: about as high as the trucks can go. To go any further requires a horse or a yak. Each person receives 35 kilos of US government-issue flour - just enough to avert a dire food emergency.

The Kirghiz nomads used to be among Central Asia's wealthiest peoples. The profile of their legendary leader, Khan Rahman Qul, and his sumptiously decorated yurt adorned the reports of numerous expeditions in the 1970s that had been searching for the breed of sheep known as Marco Polo that is common to the area. With 16,000 animals, Rahman Qul was one of Afghanistan's richest local leaders. Rahman Qul had good connections with the royal Afghan regime, which awarded the khan with the title "Pasbani Pamir" - defender of the Pamir - for his role in securing the country's northeastern border.

Rahman Qul's downfall began with the April revolution in 1978, when a faction of the Communist Party assumed power in Kabul. In the year prior to the Soviet invasion, Rahman Qul led his 250 Pamir yurt communities into Pakistani exile. While in exile, Rahman Qul negotiated with the US government over the possibility of Kirghiz nomads being allowed to breed cattle in Alaska. In the end, however, Turkey was the only country to provide the Kirghiz political asylum, as it had done before with other Turkic-speaking groups. Rahman Qul eventually decided to resettle his group in the eastern Anatolian highlands near Lake Van.

After four years in exile in Pakistan, however, the Kirghiz nomads were split over Qul's decision. For some time, rival leader Abdurrashid Khan had maintained contacts with the Russian army in 
the Little Pamir. Abdurrashid Khan's and 50 other yurt communities refused to follow Rahman Qul to Turkey.

In 1979, then Pakistani president Zia-ul Haq allowed members of the group around Abdurrashid Khan to return to Afghanistan. Abdurrashid Khan's people subsequently took control of all the pasture lands in the Little Pamir and Great Pamir regions.

This group of Kirghiz nomads remembers that time as the beginning of the heydey of trading in the region. Until the withdrawal in 1983 of 1,300 Red Army troops from their base in Bozai Gumbaz, say the herders, clothing, food, cigarettes and medical supplies had all been available in ample supply.

The current situation looks bleak by comparison. The 1,200 Kirghiz nomads living in 237 yurts own a total of just 1,400 yaks and 9,000 sheep and goats. Barely any goods are exchanged and there is neither a medical clinic nor a school. Money is unknown. All the nomads are illiterate. The man who handles their correspondence is Niyoz Ali Patuwani, a member of the Wakhi from Khandut and Abdurrashid Khan's secretary.

The Kirghiz are suffering without their traditional markets that they used to supply in winter with. cattle from the Pamir. The yearly caravans to Kabul to unload the nomads' fattened sheep have not taken place for ages and badly needed items from the capital do not arrive here anymore, either. Small-scale trade has been taking place for eight years between the Kirghiz nomads and their Pakistani neighbours in the Hunza Valley. The nomads offer their sheep and yaks in exchange for flour, tea, matches clothing and shoes.

Opium dealers from the autonomous Tajik region of Badakhshan bring their stuff to the pastures of the Pamir where they trade it for the Kirghiz nomads' sheep. Controlling the trade are local commanders from the anti-Taliban movement, who demand road use fees (toll-taxes) and other contributions. Like the Taliban, the rebels finance their fight with money from the opium trade. Both groups proclaim their imminent victory and promise to establish a fundamentalist Islamic state.

The small Kirghiz minority in Afghanistan has seen many of its members become addicted to opium over the past few years. In the winter, opium serves as both a medication and a hedge against despair. It is estimated and alleged that as many as 90 per cent of the Kirghiz nomads are addicted to opium.

Despite the fact that the nomads inhabit one of the most isolated regions of the world, their traditional herding economy has proven incredibly vulnerable to regional developments. When Rahman Qul's group emigrated to Turkey in 1982, one report called it "The Last Journey of the Kirghiz"; but it was not to be the group's final migration.

The sons of Rahman Qul (who died in 1990) are now seeking asylum in Kyrgyzstan. Haji Rahman Qul's grandchildren already study there. His opponent, Abdurrashid Khan, attempted a similar move. The government of Kyrgyzstan was ready to allow Kirghiz nomads living just over the Tajik-Afghan border in Afghanistan to resettle in the Sary-Tash region of Kyrgyzstan. But prominent Kirghiz nomads in Pamir decided to stick with their leader's plans and refused to pledge their loyalty to an unknown land. By all accounts, the nomads are not prepared to trade what little they can call their own - the pastures of the Great and Little Pamir - for an uncertain future in Kyrgyzstan.

But despite the terrible conditions, a glimmer of hope persists that things will soon be better. The lorries have left the pastures of the Pamir, but the aid workers from Focus International promise they will be back again before winter to distribute food and warm clothing.

Anyway, in October some of the cattle breeders will set off for the closest store in Hunza, travelling some 150 kilometres to trade their sheep and yaks for wheat flour to see the yurt communities through the brutal, eight-month winter. 


\section{Appendix 3: List of acronyms}

$\begin{array}{ll}\text { AKDN } & \text { Aga Khan Development Network } \\ \text { AKF } & \text { Aga Khan Foundation } \\ \text { AKRSP } & \text { Aga Khan Rural Support Programme } \\ \text { MSF } & \text { Médecins sans frontieres } \\ \text { ORA International } & \text { Orphans, Refugees and Aid International (Afghanistan/Pakistan) } \\ \text { VEW } & \text { Village extension worker } \\ \text { VO } & \text { Village organization }\end{array}$

